\title{
An Intersectional Approach towards Parental Employment in Families with a Child with a Disability: The Case of Belgium
}

Work, Employment and Society

(C) The Author(s) 2019

Article reuse guidelines: sagepub.com/journals-permissions DOI: $10.1177 / 0950017019872648$ journals.sagepub.com/home/wes

\section{Julie Vinck}

University of Antwerp, Belgium

\section{Wim Van Lancker}

University of Leuven, Belgium

\begin{abstract}
For parents with disabled children labour market participation is difficult since these children require care that exceeds typical parental care. At the same time, disabled children often live in families who belong to social categories that are associated with lower employment probabilities. However, the intersection between disability and social categories is hitherto overlooked in the literature. Drawing on a case study of Belgium, this article empirically examines to what extent parental employment is explained by the child's disability and/or the family's social disadvantages. For this, unique and largescale register data are used. The results show that (I) childhood disability overlapped with social disadvantages; (2) childhood disability inhibited parental employment; but (3) the relationship differed by social category: for single parents, parents with low educational qualifications, and parents having multiple disabled children, disability and social disadvantage reinforced each other.
\end{abstract}

\section{Keywords}

activation, childhood disability, intersectionality, parental employment, social category, social disadvantage

\section{Introduction}

Drawing on a case study of Belgium, this article empirically examines how having a disabled child overlaps with different social disadvantages and how such an intersection relates to the risk of low parental employment.

\footnotetext{
Corresponding author: Julie Vinck, University of Antwerp, Sint-Jacobstraat 2, 2000 Antwerp, Belgium. Email: julie.vinck@uantwerpen.be
} 
Over the past decades, welfare states were reoriented to support and encourage paid employment for all. In many countries, the recalibration of welfare policies was guided by the idea that income security and social integration are best ensured by paid labour (Burkhauser et al., 2016; Hemerijck, 2017). Consequently, policy reforms in many welfare states were characterised by a stronger emphasis on activation, often accompanied with the curtailment of cash benefits to avoid inactivity traps (Bonoli, 2012). In Belgium, activation was supported by simultaneously fostering job demand (mainly through reducing employers' social security contributions) and job supply (by lowering low wage employees' social security contributions and by increased monitoring and sanctioning of the unemployed) (Hemerijck and Marx, 2010). Moreover, activation policies increasingly expanded to cover people who were exempted before, such as single mothers, disabled people and caregivers (Lindsay et al., 2015; Roets et al., 2012). In fact, disability policies were mainstreamed into regular labour market programmes throughout European welfare states (Burkhauser et al., 2016; Hvinden, 2003; Marin et al., 2004).

For families with disabled children, however, parental employment is prima facie problematic (Cantillon and Van Lancker, 2013). Disabled children generally require an amount of care that exceeds typical parental care and the time required to provide such care impedes parents', especially mothers', engagement in the labour market (Brown and Clark, 2017; Stabile and Allin, 2012). On top of that, they also face higher, direct costs to pay for medical and care needs. As a corollary, families with disabled children usually have to get by on lower incomes. Given the aforementioned changes in the welfare settlement, it becomes increasingly difficult to sustain a decent living standard on only one or even no income from paid employment. As a result, these families face a high risk of poverty (Shahtahmasebi et al., 2011).

In a context in which families with disabled children are pressured to work, it is crucial to understand the mechanisms that inhibit the full realisation of their work potential. This is important since the child's disability might be only half the story. Parents of disabled children often belong to social categories that might impede their employment opportunities in their own right: they are more likely to be lower educated, single and disabled.

So, then, can parental employment be explained by the child's disability, the family's social disadvantages, or both? That is the central question of this article. Using an intersectional approach to capture combinations of multiple social disadvantages (see Zuccotti and O'Reilly (2018) for a similar approach), the aim of this article is to further our understanding of whether childhood disability overlaps with other social disadvantages in Belgium and how this intersection correlates with parental employment. To test this, large-scale register data in which information on children's disabilities is linked with information on socioeconomic characteristics and employment are used. The dataset also includes a control group of non-disabled children. In the empirical analyses, first, the overlap between the child's disability and the family's social categories (lower versus higher educated parents, single versus two parents, immigrant versus native parents, and households with versus without multiple disabled members) is investigated. Second, the relationship between having a disabled child and parental employment is examined. Finally, it is tested to what extent the employment gap differs by the aforementioned social categories. 


\section{Theoretical framework and previous research}

It is theorised that an intersectional approach is needed to understand the employment gap between families with and without disabled children. This approach assumes that multiple social disadvantages not only independently affect one's employment chances but might also reinforce one another (McBride et al., 2015; Mooney, 2016; Tapia and Alberti, 2019). Therefore, their association with employment should be analysed jointly instead of separately.

There is a wealth of theoretical and empirical literature on intersectionality in different research fields (Bilge, 2010; Cho et al., 2013; Choo and Ferree, 2010; Collins, 2015; Dhamoon, 2011; Hancock, 2007; McCall, 2005; Walby, 2007; Walby et al., 2012; YuvalDavis, 2006). In this article, an inter-categorical approach towards intersectionality is adopted. According to McCall (2005), this approach allows the study of the complexities of multiple sources of inequalities through the analysis of 'existing analytical categories to document relationships of inequality among social groups and changing configurations of inequality among multiple and conflicting dimensions' (2005: 1773). In doing so, all dimensions of the social categories are considered, meaning that both advantages and disadvantages are simultaneously analysed. Such an approach allows to gain analytical purchase on how the category of 'childhood disability' overlaps with and relates to other social disadvantages such as single parenthood (versus two-parent households), lower educational qualifications (versus higher educational qualifications), migration background (versus native parents) and the presence of other disabled family members (parent(s), other child(ren), other adult(s) versus none). As such, a disabled child living with a low-skilled immigrant single mother is placed at the intersection of childhood disability with the disadvantage of low parental educational qualifications, single motherhood and parental migration background. The analytical assumption is that the experiences at this intersection will differ from those at other intersections, such as a disabled child living in a native-born couple family.

It is clear from the literature that disabled children require additional care that exceeds typical parental care (Owen et al., 2003). Specifically, maternal labour supply is sensitive to the level of caregiving responsibilities. As such, there is a 'direct' employment effect of having a disabled child since mothers (and less often fathers) will reduce their working hours or leave the labour market altogether to cope with the care burden (Brown and Clark, 2017; Stabile and Allin, 2012). This pattern is found in Australia (Crettenden et al., 2014; Gordon et al., 2007; Zhu, 2016), the United States (DeRigne, 2012; Porterfield, 2002; Powers, 2001, 2003; Wasi et al., 2012), Norway (Hauge et al., 2013), Sweden (Olsson and Hwang, 2006), Taiwan (Chou et al., 2018) and Belgium (Debacker, 2007; Van Landeghem et al., 2007). In contrast, Brekke and Nadim (2016), also for Norway, find that employment probabilities of parents with and without disabled children are comparable, which they attribute to gender-egalitarian policies. They do find a strong, negative effect on average earnings, however. Additionally, having a disabled child can affect parental employment indirectly through deteriorated parental health (Brekke and Nadim, 2016; Brekke et al., 2017).

The size of the employment gap between families with and without disabled children not only depends on the institutional context but also on the household type, type and 
severity of the disability, and age of the child. Some authors find that the negative employment impact is larger for single than partnered mothers (Powers, 2001, 2003; Wasi et al., 2012), while others find the opposite (Gordon et al., 2007; Porterfield, 2002) or find that it mainly depends on the disability type (Lu and Zuo, 2010). Regarding the latter, DeRigne (2012) presents evidence that the employment impact of having a disabled child is strongest when children have mental or developmental disabilities whereas Lu and Zuo (2010) and Wasi et al. (2012) find the strongest impact in families with physically disabled children. Nonetheless, the single most consistent finding in the literature is that the more severe the child's disability, the higher the care burden, the more difficult it is to sustain paid employment (Chou et al., 2018; Crettenden et al., 2014; DeRigne, 2012; Gordon et al., 2007; Hauge et al., 2013; Leiter et al., 2004; Lu and Zuo, 2010; Wasi et al., 2012). Only Powers (2003) does not find a substantial difference by the severity of the child's disability in the US. Finally, for non-disabled children, the care burden tends to lessen when a child ages, in particular when a child reaches school age. This frequently coincides with parents, mainly mothers, resuming or increasing employment. For parents with disabled children, however, the opposite may hold since the care burden often increases or does not decrease as much when their child gets older (Crettenden et al., 2014; Gordon et al., 2007; Haveman et al., 1997).

In order to fully understand the employment gap, it is indispensable to investigate the intersection between the child's disability and other social categories that increase a family's labour market vulnerability. There is a persistent link between disadvantaged socioeconomic status and poor health (Case et al., 2002; Goldman, 2001; Warren, 2009), and disabled children are overrepresented in households embodying social disadvantages that jeopardise parental employment. Parents of disabled children are more likely to have lower educational levels (Bauman et al., 2006; OECD, 2010; Powers, 2003; Sebrechts and Breda, 2012; Van Landeghem et al., 2007; Wasi et al., 2012), are more frequently single parents (Bauman et al., 2006; Blackburn et al., 2010; Clarke and McKay, 2008; Emerson and Hatton, 2007; Fujiura and Yamaki, 2000; Powers, 2003; Reichman et al., 2008; Risdal and Singer, 2004; Sebrechts and Breda, 2012; Wasi et al., 2012), and are more often disabled themselves (Blackburn et al., 2010; RKW, 2013; Sebrechts and Breda, 2012; Van Landeghem et al., 2007). The results are less straightforward for the parents' migration background. Some authors find no difference with respect to migration status (Bauman et al., 2006; Emerson and Hatton, 2007; Fujiura and Yamaki, 2000), while others show that children with a migration background are more (Kawa et al., 2016; Wasi et al., 2012) or less likely (Blackburn et al., 2010; Emerson, 2012; Singh and Lin, 2013) to have a disability, depending on the disability type and countries of origin investigated.

These social disadvantages clearly affect one's employment potential independent of having a disabled child. It is for instance well established that strong educational discrepancies in work-care arrangements still exist (Debacker, 2008; Konietzka and Kreyenfeld, 2010; Stahl and Schober, 2018), with highly educated mothers being much more likely to work compared with low-skilled mothers. Furthermore, adults with disabilities are largely marginalised from the labour markets in the majority of welfare states (Grammenos, 2013; Vornholt et al., 2018) and often live in work-poor households (Nys et al., 2016). Balancing paid work with childcare is a major challenge for single parents, and strongly related to welfare state policies such as leave policies and childcare 
(Nieuwenhuis and Maldonado, 2018). Finally, it is well established that immigrant families have lower probabilities to attain paid employment in many Western welfare states, including Belgium (Corluy et al., 2015; Eurostat, 2011; OECD, 2012).

So, while it is clear that (1) having a disabled child is associated with reduced parental employment and (2) disabled children often live in families who belong to social categories that are associated with lower employment probabilities, there is a lack of research on the link between the two: can parental employment be explained by the child's disability, the family's social disadvantages, or both?

\section{Research questions and hypotheses}

This article is structured around three research questions. First, how does the category of 'childhood disability' overlap with other social disadvantages (RQ1)? Second, do parents with disabled children face an employment gap compared to parents without disabled children (RQ2)? Finally, to what extent is the parental employment gap stronger at the intersection of the child's disability and the family's other social disadvantages (RQ3)?

Regarding RQ1, it is expected that having a disabled child overlaps with having lower educational qualifications (H1.1), being a single parent (H1.2) and living with other disabled household members (H1.3). Previous literature remains inconclusive on the overlap with migration background; therefore, this article examines the nature of this relationship (H1.4). For RQ2, the expectation is that parents with disabled children work less than parents of non-disabled children (H2). Finally, with respect to RQ3, the literature has hitherto not applied an intersectional approach. This article investigates whether the experience of multiple social disadvantages adds up, reinforces, or offsets each other in relation to parental employment $(\mathrm{H} 3)$.

\section{Data, methods and variables}

A unique and large-scale register dataset is used to gain insight into the intersection of the child's disability and the family's social disadvantages, and to estimate their reciprocal relationship with parental employment. Microdata from the Datawarehouse Labour Market and Social Protection (DWH LM\&SP) is linked with the latest Belgian Census. The DWH LM\&SP compiles administrative data from Belgian social security agencies as well as information on personal and household characteristics from the National Register. From the 2011 Census, a snapshot of the total Belgian population on 1 January 2011, information on the parental educational level is extracted. The data consist of a random sample of $50 \%$ of children below 21 who lived in Belgium and received the supplemental child benefit on 31 December 2010 and an equally large randomly drawn control group of children below 21 who did not receive the supplemental child benefit.

To obtain the supplemental child benefit, doctors of the Federal Government Service for Social Security (FGS) assess the care needs owing to the disability and score the child on a 36-point scale making use of a standardised criteria list. The purpose of these criteria is to gauge the consequence of the child's disability for the child's (1) physical and mental health; (2) self-reliance; and (3) family. There is no income test, but the benefit amount is related to the score on the 36-point scale (see Vinck et al. (2019) for more 
information on the recognition procedure). The benefit varies between $€ 80$ and more than $€ 500$ per month. In $2015,2.37 \%$ of children under 21 received the supplemental child benefit (FAMIFED, 2016). Thus, the category of 'childhood disability' that is applied in this article, is an administrative recognition of the disability as evaluated by control doctors of the FGS.

After deletion of children having disabled siblings from the control group, children whose parents' employment status cannot be determined with certainty, ${ }^{1}$ children who have missing information on either variable included in the analyses, and selecting the youngest (disabled) child per household, there are 17,481 disabled children and 17,934 non-disabled children in the unweighted sample.

Logistic and linear regressions are applied to answer the research questions. Regarding RQ1, the overlap between the child's disability and the family's social disadvantages is tested through a logistic regression. The dependent variable is whether a child receives the supplemental child benefit (yes/no). As independent variables, the child's sex and age (categorised into $0-3,4-5,6-11,12-17$, or 18-20 years old) are included, together with the social categories the child belongs to (single parent household (yes/no); parental educational qualifications; parental country of birth; and living together with other disabled family members (yes/no)). The parents' educational qualifications are operationalised using the International Standard Classification of Education (ISCED), differentiating between low-skilled (ISCED 0-2: lower secondary education or less), medium-skilled (ISCED 3-4: secondary education) and high-skilled parents (ISCED 5-6: tertiary education). A dominance criterion is applied, meaning that the highest education level of one of the parents is assigned to the household. For country of birth, a distinction is made between Belgium, other European Union countries (EU27) and non-EU27 countries. A 'closeness criterion' is applied, meaning that if at least one parent is born in Belgium or in another EU27 country, the household is considered to have a Belgian or EU27 migration background. Only when both parents are born outside the EU27, the household is considered to have a non-EU27 migration background.

With respect to RQ2 and RQ3, three stepwise linear regression models are employed to estimate the employment gap between families with and without disabled children and examine its explanatory factors (i.e. the child's disability and/or the family's social disadvantages). The dependent variable measures parental employment jointly by an indicator labelled 'household work intensity'. It captures the degree to which all working-age household members together (individuals aged 18-59 years, excluding students 18-24 years) participate on the labour market. ${ }^{2}$ It is defined as the ratio between their total number of months worked (expressed in full-time equivalents) and the total number of months that they could, in theory, have worked. The ratio goes from zero to one, with zero indicating that no working-age household member participated in the labour market in that year, whereas a score of one implies that they all worked full-time all year. In case the actual employment status differs from the contractual situation, the household work intensity variable was recoded to zero. ${ }^{3}$ Model 1 includes the severity of the child's disability as measured by their score on the 36-point scale, and five control variables: region of residence; age and sex of the child; age of the mother, or if the mother is not present the age of the father (centred around the mean); and the number of siblings. Model 2 adds variables on the aforementioned social categories (family type; parental educational qualifications; 
parental country of birth; and presence of other disabled family members). To depict the presence of other disabled family members, three dummy variables are now included: one for the parents, one for the other children and one for the other adults. Finally, in Model 3, interaction effects between the severity of the child's disability and the social categories are introduced to disentangle the disability and social category effects.

A population weight is applied to both samples to represent the full Belgian population of disabled and non-disabled children. Descriptive information on all variables of interest is presented in Appendix 1: in 2010, 2\% of Belgian children below 21 have a recognised disability. As sensitivity checks, the analyses were performed without the weight (Appendix 2), excluding the extended families (Appendix 3) and for mothers and fathers separately (Appendix 4, this is elaborated upon in the discussion section) with no impact on the interpretation of the results.

\section{Results}

\section{How does childhood disability overlap with social disadvantages?}

The results regarding RQ1 showed that several social disadvantages overlapped with childhood disability in Belgium (Table 1). Disabled children more frequently lived with low- and medium-skilled parents (H1.1), single parents (H1.2) and other disabled household members (H1.3). Yet, parents born abroad (in EU27 or non-EU27 countries) were significantly less likely to have a child with a recognised disability compared to native parents (H1.4).

Since immigrants in Belgium are more often lower educated than in other countries (Corluy and Verbist, 2014), it is useful to further investigate this (Appendix 5). An interaction between parental education and country of birth revealed no significant educational gradient in the likelihood of having a disabled child for EU27 and non-EU27 parents (Figure A5.1). Yet, low- and medium-skilled EU27 parents and low-skilled non-EU27 parents were less likely to have a child with a recognised disability than natives, while there was no significant difference with natives for high-skilled EU27 parents, and medium- and high-skilled non-EU27 parents. Corroborating the contradictory findings in the literature, in Belgium too the association of childhood disability with migration background depends on the region of origin. If anything, parents with a migration background were less likely to have a disabled child compared with natives if they have low educational qualifications.

Finally, disabled children were more often older and boys compared to non-disabled children, which is in line with previous research (Table 1; e.g. Blackburn et al., 2010; Emerson and Hatton, 2007; Van Landeghem et al., 2007).

\section{Parental employment gap: Childhood disabilities or social disadvantages?}

There was a significant negative relationship between the child's disability and parental employment in each model (H2, Table 2). Moreover, higher scores on the administrative severity scale used for the supplemental child benefit put more pressure on parental employment. Model 1 showed that the 'disability effect' ranged from a parental employment gap of 1.3 percentage points (pp) for the lowest number of points (6) to a gap of $35.6 \mathrm{pp}$ for the highest severity score observed (32). ${ }^{4}$ 
Table I. Logistic regression on having a disabled child, Belgium, 2010.

\begin{tabular}{lc}
\hline $0-20$ years & Odds ratios \\
\hline Constant & $0.003 * * *$ \\
& $(0.000)$
\end{tabular}

\section{Social categories}

Single parent

Country of birth parents (Belgium ref.)

EU27

Non-EU27

Parental education (High-skilled ref.)

Medium-skilled

Low-skilled

Other disabled household member(s) (None ref.)

Yes, at least one

\section{Child characteristics}

Age (0-3 years ref.)

4-5 years

6-II years

$12-17$ years

Male

Model fit

Log pseudolikelihood

Prob $>\mathrm{chi}^{2}$ 0.000

N

Source: Own calculations on DWH LM\&SP, year 2010 and Census, year 20I I. See 'Data, methods and variables'. Notes: no disability is base outcome. Robust standard errors in parentheses. ${ }^{*} p<0.05$; ${ }^{*} p<0.0$ I;

$*_{* *} p<0.00 \mathrm{I}$. Odds ratios $<\mathrm{I}$ indicate a lower risk of having a disability, odds ratios $>1$ indicate a higher risk, compared to the reference category.

When the different social category variables were included in Model 2, the magnitude of the disability effect was reduced by $39 \%$. Single parenthood, having a migration background, being low- or medium-skilled, or the presence of other disabled household members had a negative impact on a household's work intensity. 
Table 2. Stepwise multivariate regression on household work intensity, Belgium, 2010.

\begin{tabular}{|c|c|c|c|}
\hline Belgium (0-20 years) & Model I & Model 2 & Model 3 \\
\hline Constant & $\begin{array}{l}0.805^{* * * *} \\
(0.007)\end{array}$ & $\begin{array}{l}0.907 * * * * \\
(0.006)\end{array}$ & $\begin{array}{l}0.906 * * * \\
(0.006)\end{array}$ \\
\hline \multicolumn{4}{|l|}{ Disability } \\
\hline Severity of disability & $\begin{array}{l}-0.013^{* * * *} \\
(0.000)\end{array}$ & $\begin{array}{l}-0.008 * * * * \\
(0.000)\end{array}$ & $\begin{array}{c}-0.003 * * \\
(0.001)\end{array}$ \\
\hline \multicolumn{4}{|l|}{ Social categories } \\
\hline Single parent & & $\begin{array}{l}-0.223 * * * \\
(0.006)\end{array}$ & $\begin{array}{l}-0.222^{* * * *} \\
(0.007)\end{array}$ \\
\hline \multicolumn{4}{|l|}{ Country of birth parents (Belgium ref.) } \\
\hline EU27 & & $\begin{array}{c}-0.034^{*} \\
(0.015)\end{array}$ & $\begin{array}{c}-0.034^{*} \\
(0.016)\end{array}$ \\
\hline Non-EU27 & & $\begin{array}{l}-0.145 * * * \\
(0.011)\end{array}$ & $\begin{array}{l}-0.145^{* * * *} \\
(0.011)\end{array}$ \\
\hline \multicolumn{4}{|l|}{ Parental education (High-skilled ref.) } \\
\hline Medium-skilled & & $\begin{array}{l}-0.111 \text { I*** } \\
(0.004)\end{array}$ & $\begin{array}{l}-0.110 * * * \\
(0.004)\end{array}$ \\
\hline Low-skilled & & $\begin{array}{l}-0.247^{* * * *} \\
(0.007)\end{array}$ & $\begin{array}{l}-0.247^{* * * *} \\
(0.007)\end{array}$ \\
\hline \multicolumn{4}{|c|}{ Other disabled household member(s), excluding siblings (None ref.) } \\
\hline Parent(s) & & $\begin{array}{c}-0.267^{* * *} \\
(0.015)\end{array}$ & $\begin{array}{c}-0.267^{* * *} \\
(0.016)\end{array}$ \\
\hline Other adult(s) & & $\begin{array}{l}-0.166 * * * \\
(0.029)\end{array}$ & $\begin{array}{l}-0.168^{* * * *} \\
(0.030)\end{array}$ \\
\hline \multicolumn{4}{|l|}{ Interaction $\times$ severity of disability } \\
\hline Single parent $\times$ severity of disability & & & $\begin{array}{l}-0.006 * * * \\
(0.001)\end{array}$ \\
\hline \multicolumn{4}{|l|}{ Country of birth parents (Belgium ref.) } \\
\hline EU $27 \times$ severity of disability & & & $\begin{array}{c}-0.001 \\
(0.003)\end{array}$ \\
\hline Non-EU27 $\times$ severity of disability & & & $\begin{array}{c}0.001 \\
(0.002)\end{array}$ \\
\hline \multicolumn{4}{|l|}{ Parental education (High-skilled ref.) } \\
\hline Medium-skilled $\times$ severity of disability & & & $\begin{array}{l}-0.004^{* * *} \\
(0.001)\end{array}$ \\
\hline Low-skilled $\times$ severity of disability & & & $\begin{array}{c}-0.002^{*} \\
(0.001)\end{array}$ \\
\hline \multicolumn{4}{|l|}{ Other disabled household members } \\
\hline Other adult(s) $\times$ severity of disability & & & $\begin{array}{c}0.007 \\
(0.004)\end{array}$ \\
\hline Parent(s) $\times$ severity of disability & & & $\begin{array}{c}0.000 \\
(0.002)\end{array}$ \\
\hline Sibling(s) $\times$ severity of disability & & $\begin{array}{c}-0.004 * * \\
(0.001)\end{array}$ & $\begin{array}{c}-0.003 * * \\
(0.001)\end{array}$ \\
\hline
\end{tabular}


Table 2. (Continued)

\begin{tabular}{|c|c|c|c|}
\hline Belgium (0-20 years) & Model I & Model 2 & Model 3 \\
\hline \multicolumn{4}{|l|}{ Age of the child ( $0-3$ years ref.) } \\
\hline $4-5$ years $\times$ severity of disability & & & $\begin{array}{c}-0.003^{*} \\
(0.001)\end{array}$ \\
\hline $6-11$ years $\times$ severity of disability & & & $\begin{array}{c}-0.003^{* *} \\
(0.001)\end{array}$ \\
\hline $12-17$ years $\times$ severity of disability & & & $\begin{array}{c}-0.001 \\
(0.001)\end{array}$ \\
\hline $18-20$ years $\times$ severity of disability & & & $\begin{array}{c}0.002 \\
(0.002)\end{array}$ \\
\hline \multicolumn{4}{|l|}{ Control variables } \\
\hline \multicolumn{4}{|l|}{ Age of the child ( $0-3$ years ref.) } \\
\hline $4-5$ years & $\begin{array}{l}0.056 * * * \\
(0.008)\end{array}$ & $\begin{array}{l}0.063 * * * \\
(0.006)\end{array}$ & $\begin{array}{l}0.064^{* * * *} \\
(0.006)\end{array}$ \\
\hline $6-11$ years & $\begin{array}{l}0.077^{* * *} \\
(0.007)\end{array}$ & $\begin{array}{l}0.091 \text { *** } \\
(0.006)\end{array}$ & $\begin{array}{l}0.092^{\text {**** }} \\
(0.006)\end{array}$ \\
\hline $12-17$ years & $\begin{array}{l}0.099 * * * \\
(0.008)\end{array}$ & $\begin{array}{l}0.119 \text { **** } \\
(0.007)\end{array}$ & $\begin{array}{l}0.119 \text { **** } \\
(0.007)\end{array}$ \\
\hline $18-20$ years & $\begin{array}{l}0.060^{* * * *} \\
(0.012)\end{array}$ & $\begin{array}{l}0.098 \text { **** } \\
(0.010)\end{array}$ & $\begin{array}{l}0.098^{* * * *} \\
(0.01 \mathrm{I})\end{array}$ \\
\hline Male & $\begin{array}{c}-0.001 \\
(0.004)\end{array}$ & $\begin{array}{c}0.001 \\
(0.004)\end{array}$ & $\begin{array}{c}0.001 \\
(0.004)\end{array}$ \\
\hline \multicolumn{4}{|l|}{ Region of residence (Flanders ref.) } \\
\hline Brussels & $\begin{array}{l}-0.188 * * * \\
(0.011)\end{array}$ & $\begin{array}{l}-0.073 * * * * \\
(0.009)\end{array}$ & $\begin{array}{c}-0.073^{* * * *} \\
(0.009)\end{array}$ \\
\hline Wallonia & $\begin{array}{l}-0.123 * * * \\
(0.005)\end{array}$ & $\begin{array}{l}-0.073 * * * \\
(0.004)\end{array}$ & $\begin{array}{l}-0.073^{\text {**** }} \\
(0.004)\end{array}$ \\
\hline Age of mother (centred around the mean) & $\begin{array}{l}-0.006 \text { **** } \\
(0.001)\end{array}$ & $\begin{array}{l}-0.004 * * * * \\
(0.000)\end{array}$ & $\begin{array}{l}-0.004^{* * * *} \\
(0.000)\end{array}$ \\
\hline Number of siblings ( $<21$ years) & $\begin{array}{l}-0.026 \text { **** } \\
(0.003)\end{array}$ & $\begin{array}{l}-0.025^{* * * *} \\
(0.002)\end{array}$ & 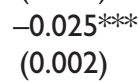 \\
\hline \multicolumn{4}{|l|}{ Model fit } \\
\hline Log likelihood & -6805.48 & -285.30 & -280.60 \\
\hline $\mathrm{R}^{2}$ & 0.0835 & 0.3658 & 0.3660 \\
\hline Likelihood-ratio test compared to $\mathrm{M}$-I & & 13040.37 & 9.39 \\
\hline Prob $>$ chi $^{2}$ compared to $\mathrm{M}-\mathrm{I}$ & & 0.000 & 0.586 \\
\hline$N$ & 35415 & 35415 & 35415 \\
\hline
\end{tabular}

Source: own calculations based on DWH LM\&SP, year 2010 and Census, year $201 \mathrm{I}$. Notes: robust standard errors in parentheses. ${ }^{*} p<0.05$, ${ }^{* *} p<0.0 \mathrm{I}$, ${ }^{* * *} p<0.00 \mathrm{I}$.

In Model 3, the association between childhood disability and parental employment was tested at the intersection with other social categories by means of interactions between the severity of the child's disability and these social categories. The results showed that the employment gap experienced by parents of a disabled child persisted, 
meaning that the negative association between having a disabled child and parental employment could not be solely explained by these social disadvantages. The household work intensity was lower in all families with a disabled child. Yet, the significant interaction effects suggest that the association differed by social category. For single parents, parents with low and medium educational qualifications and parents having multiple disabled children, the risk of low parental employment is reinforced at the intersection (H3). In fact, for these groups, the disability effect was about one to two times as large compared to partnered parents, parents with high educational qualifications and parents without other disabled children, respectively. For parents with a migration background, parents who are disabled themselves or with other disabled adults in their household, no significant interaction effect was found. These social disadvantages did not reinforce the negative association between childhood disability and parental employment (H3).

Figure 1 visualises these results. It shows the combined effect of childhood disability and belonging to a particular social category for disabled children with a mean severity score (see Appendix 6 for -1 and +1 standard deviation from the mean). The figure distinguishes between the effect at the intersection of childhood disability and the dimension of the social category (i.e. disability effect plus interaction effect, crosshatched part of the bar) and the effect due to belonging to that particular dimension of the

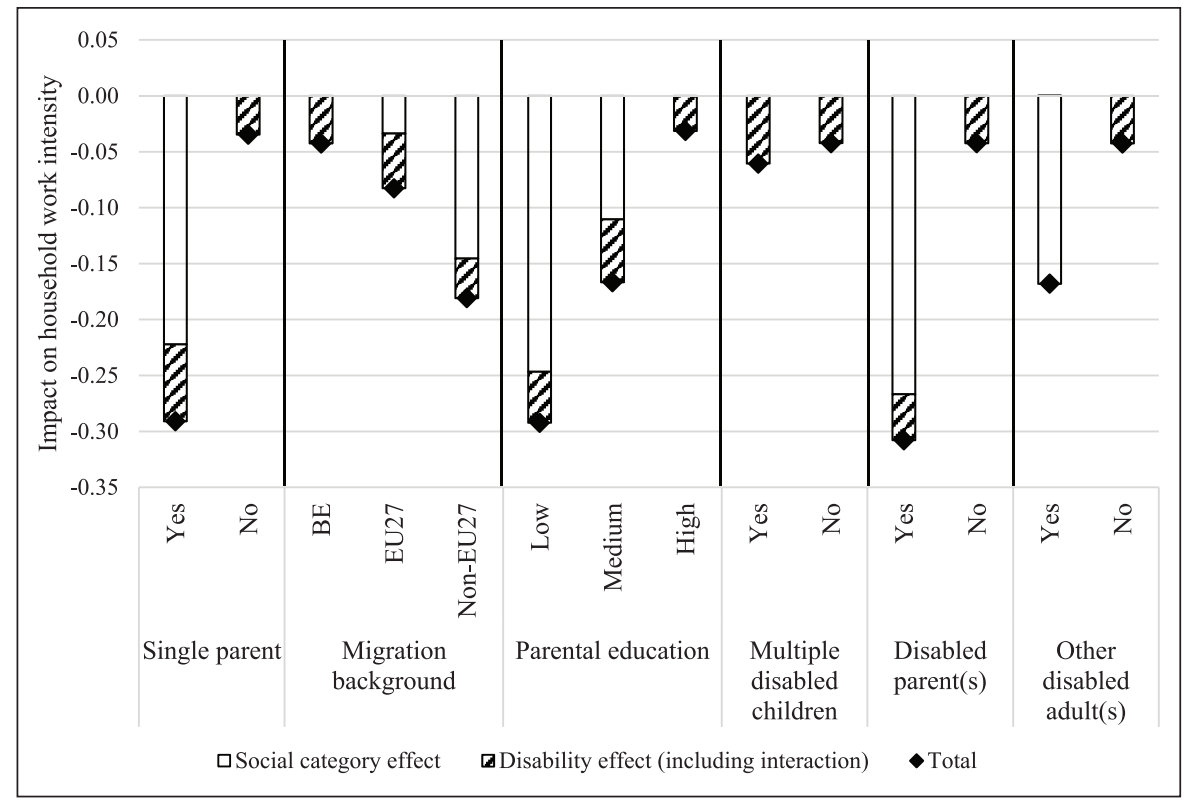

Figure I. Marginal effects of having a disabled child with the mean severity score on household work intensity by social category, for average values of other variables in Model 3 from Table 2, Belgium, 2010.

Source: Own calculations based on DWH LM\&SP, year 2010 and Census, year 20I I.

Notes: The figure presents the marginal effect on household work intensity by social category for families with a disabled child who has a mean severity score (I0.84326 (5.843258 on the recoded scale)). BE, Belgium. 
social category (i.e. white part of the bar). For instance, single parents with a disabled child had a lower labour market participation because they are single parents (i.e. social category effect, white part of the bar), but also because the effect of childhood disability is stronger at the intersection (i.e. black and white cross-hatched part of the bar); compared to two-parent families the association between childhood disability and parental employment was twice as large.

To sum up, all parents with a disabled child were less likely to work compared to parents with non-disabled children. This association was stronger for higher severity of the disability. The employment gap was only in part explained by the family's social disadvantages. Importantly, the disability effect was stronger at the intersection of childhood disability with single parenthood, lower parental educational qualifications and the presence of other disabled children in the household. The effect was not stronger, however, at the intersection with migration background, parental disabilities or the presence of other disabled adults in the household.

\section{Discussion and conclusion}

The key contribution of this article is that it advances an intersectionality approach to the analysis of labour market disadvantage associated with childhood disability. Following McBride et al.'s (2015) call to apply an intersectional lens towards issues of work and employment, in this article it was found that: (1) childhood disability overlapped with other social categories that are associated with lower employment probabilities, such as single parenthood, lower educational qualifications and the presence of other disabled household members; (2) childhood disability inhibited parental employment; but (3) the relationship differed by social category. At the intersection of childhood disability with single parenthood, lower levels of parental education or the presence of other disabled children in the household, the negative association between childhood disability and parental employment was stronger. Yet, at the intersection of childhood disability with migration background, parental disability or disability of other adult household members, no reinforcing effect could be discerned. Thus, not all sources of disadvantage strengthen one another. The intersectionality approach uncovers multiple sources of disadvantage faced by families with disabled children in today's labour markets.

From the point of view of parents, having a disabled child is a disadvantage that contributes to the experience of inequalities in its own right as well as at the intersection with other social disadvantages where the relationship can be intensified. These results add to what McCall (2005) has called the 'complexity of intersectionality'. Although the point of view of children was not studied in this article, the analysis shows that sources of parental disadvantage can be derived from the social categories children belong to.

Several limitations of this study should be mentioned. First, the definition of childhood disability is based on an administrative measure tied to the allocation of supplemental child benefits in Belgium. Such recognised disability presumably does not capture all disabled children. In Vinck et al. (2019), the non-take-up rate of the supplemental child benefit is estimated to be at least $10 \%$. However, the results reported in this article are in line with previous research on Flemish data (Sebrechts and Breda, 2012; Van Landeghem et al., 2007). As these authors apply a broader disability definition, 
including also children with increased care needs who are not recognised for the supplemental child benefits, it is safe to assume that the findings presented here can be extended to disabled children without a recognised disability as well.

Second, the household work intensity indicator measures the labour market participation of both parents taken together. It corresponds with one of the European lead indicators to evaluate the EU2020 at-risk-of-poverty or social exclusion target (Ward and Özdemir, 2013). However, the indicator does not allow to disentangle which parent bears the burden of the child's increased care needs. When analyses are performed on the less detailed employment status (yes/no) of mothers and fathers separately, the same patterns more or less hold true, though they are stronger for mothers than they are for fathers (Appendix 4). In line with previous research, gender inequalities are intensified among families with disabled children. Future research ought to look more in detail into the gendered employment effects of having a disabled child in Belgium.

Third, the cross-sectional data only allow to assess associations. To unpack the causal relationships between childhood disabilities and other social disadvantages, and how their intersection affects parental employment, the exploration of longitudinal data is necessary. This is potentially an important avenue for future research.

Fourth, the use of formal and informal childcare arrangements could not be controlled for in the analyses. Both care use dimensions obviously play an indispensable role in reconciling work and family life. Yet, previous research showed that in the majority of EU countries, children aged 0-2 years from disadvantaged backgrounds make less use of formal childcare arrangements than their more advantaged counterparts (Ghysels and Van Lancker, 2011; Pavolini and Van Lancker, 2018; Van Lancker, 2013). For some of these countries, including Belgium, this is also true for informal childcare (Van Lancker, 2013). Moreover, the available research for Flanders indicates that formal and informal childcare among disabled children only plays a limited role in responding to the increased care burden faced by their parents (Van Landeghem et al., 2007). They usually have little access to these provisions due to their disadvantaged socioeconomic position (Sebrechts and Breda, 2011). This again points to the importance of adopting an intersectionality approach towards investigating these issues.

Related to the previous point, (semi-)residential or ambulatory care arrangements and enrolment in a special or inclusive educational setting (for which recognitions from the Flemish Agency for Persons with a Disability (FAPD) and the Pupil Guidance Centre are needed in Flanders) are important sources of care support for families with disabled children. Yet, only $47 \%$ of Flemish children receiving the supplemental child benefit make use of any FAPD care provision (Vinck et al., 2019). Additionally, even in families who combine the two collective types of care arrangements (special education and (semi-)residential care), nearly half the mothers are not participating in the labour market (Van Landeghem et al., 2007). As a corollary, for families who do not make use of any support measure, combining work with the increased care demands could be even more difficult.

Finally, the observation that low-skilled migrant parents are less likely to have a child with a recognised disability might be related to issues of non-take-up (Van Oorschot, 1996). These parents perhaps lack knowledge on the benefit's existence and the recognition procedure, they may fear the stigma attached to disabilities, encounter more 
difficulties in overcoming administrative hurdles, or the doctors conducting the medical examination might be inclined to ascribe the child's developmental delay to cultural differences and language delays and hence reject their application (Kawa et al., 2016; Vinck et al., 2019). It could also be hypothesised that length of stay is an important omitted variable here, since the issues related to non-take-up might be particularly salient to newly arrived immigrants. Available data do not allow us to address this question here, but it remains an open question for future research.

In a context where disability policies are increasingly mainstreamed into regular labour market programmes and families with disabled children are pressured to work, the analyses presented in this article suggest two policy implications that extend beyond the case of Belgium.

First, as families with disabled children experience an employment gap, irrespective of their social disadvantages, it is clear that parents of disabled children face an additional challenge to combine work and care. This suggests that the activation of families with disabled children will be difficult to achieve without increased support provided to these families. Allowing parents with disabled children to resume, retain or reinforce their labour market participation presupposes that the access to high-quality formal care provisions adapted to the child's care needs is improved for their parents, so (part of) the care can be outsourced. This could help to reduce the disability gap for all families. Moreover, as families with disabled children in disadvantaged social categories experience an increased disability gap, these care services should be in particular available for these social groups as well. This means that the aforementioned socioeconomic inequalities in care service use should be addressed.

Second, extra care support alone will not suffice for these families. The general activation of individuals in disadvantaged social categories matters as well. This calls for improving the labour market opportunities for the low-skilled, single parents, migrants and disabled individuals. If welfare states succeed in activating parents belonging to these social groups, this will be beneficial for families with disabled and non-disabled children alike. Complementary to this, parents of disabled children should be provided with greater flexibility in their jobs (e.g. being able to organise their own time), which will offer them more possibilities to combine work and care (e.g. Crettenden et al., 2014). This is probably the most challenging for the jobs in which people belonging to these disadvantaged social categories are employed (Kossek and Lautsch, 2018).

To conclude, in order to properly understand the employment patterns of parents with disabled children, the results presented here suggest that childhood disability is an important social category that should not be investigated in isolation but at the intersection with other social categories that are negatively related to parental employment as well. An inter-categorical intersectional approach is a fruitful way of analysing complex patterns of inequalities in today's labour market.

\section{Funding}

The authors declared the following financial support for the research, authorship, and/or publication of this article: This work was supported by the Research Foundation Flanders (FWO, grant $1113818 \mathrm{~N})$. 


\section{Notes}

1. The parents' employment participation builds upon an administrative record indicating in which branch of the social security system one is registered. If parents do not occur in any social security record, they are assigned to the 'other' category and assumed to be not working. However, there is no information to assume this and hence the 'other' category is rather diverse, including, for example, housewives, rentiers, outbound frontier workers and international officials and diplomats. Therefore, parents belonging to this 'other' group at any point in 2010 are excluded from the analyses.

2. Descriptive analyses show that $9 \%$ and $10 \%$ of disabled and non-disabled children, respectively, live in an extended family (at least one other working-age household member).

3. During $2010,3 \%$ of disabled and $2 \%$ of non-disabled children had parents who were not working but had a work intensity larger than zero.

4. As children with 1 to 5 points on the severity scale are not observed in the data, this variable is rescaled by subtracting 5 points of each individual's total. Only $0.13 \%$ of Belgian children receiving supplemental child benefits in 2010 have less than 6 points on the severity scale (FAMIFED, 2017).

\section{References}

Bauman LJ, Silver EJ and Stein REK (2006) Cumulative social disadvantage and child health. Pediatrics 117(4): 1321-1328.

Bilge S (2010) Recent feminist outlooks on intersectionality. Diogenes 57(1): 58-72.

Blackburn CM, Spencer NJ and Read JM (2010) Prevalence of childhood disability and the characteristics and circumstances of disabled children in the UK: secondary analysis of the Family Resources Survey. BMC Pediatrics 10(21): 1-12.

Bonoli G (2012) Active labour market policy and social investment: a changing relationship. In: Morel N, Palier B and Palme P (eds) Towards a Social Investment Welfare State? Ideas, Policies and Challenges. Bristol: The Policy Press, 181-204.

Brekke I and Nadim M (2016) Gendered effects of intensified care burdens: employment and sickness absence in families with chronically sick or disabled children in Norway. Work, Employment and Society 31(3): 391-408.

Brekke I, Albertini Früh E, Kvarme LG, et al. (2017) Long-time sickness absence among parents of pre-school children with cerebral palsy, spina bifida and down syndrome: a longitudinal study. BMC Pediatrics 17: 26.

Brown TJ and Clark C (2017) Employed parents of children with disabilities and work family life balance: a literature review. Child \& Youth Care Forum 46(6): 857-876.

Burkhauser RV, Daly MC and Ziebarth NR (2016) Protecting working-age people with disabilities: experiences of four industrialized nations. Journal for Labour Market Research 49(4): 367-386.

Cantillon B and Van Lancker W (2013) Three shortcomings of the social investment perspective. Social Policy and Society 12(4): 553-564.

Case A, Lubotsky D and Paxon C (2002) Economic status and health in childhood: the origins of the gradient. The American Economic Review 92(5): 1308-1334.

Cho S, Crenshaw KW and McCall L (2013) Toward a field of intersectionality studies: theory, applications, and praxis. Signs 38(4): 785-810.

Choo HY and Ferree MM (2010) Practicing intersectionality in sociological research: a critical analysis of inclusions, interactions, and institutions in the study of inequalities. Sociological Theory 28(2): 129-149. 
Chou Y-C, Kröger T and Pu C-Y (2018) Underemployment among mothers of children with intellectual disabilities. Journal of Applied Research in Intellectual Disabilities 31(1): 152-158.

Clarke H and McKay S (2008) Exploring Disability, Family Formation and Break-Up: Reviewing the Evidence. Birmingham: Institute of Applied Social Studies, University of Birmingham on Behalf of the Department for Work and Pensions.

Collins PH (2015) Intersectionality's definitional dilemmas. Annual Review of Sociology 41(1): $1-20$.

Corluy V and Verbist G (2014) Can education bridge the gap? Employment position of immigrants in Belgium. ImPRovE Working Papers 14/02. Antwerp: Herman Deleeck Centre for Social Policy.

Corluy V, Haemels J, Marx I, et al. (2015) The labour market position of second-generation immigrants in Belgium. NBB Working Paper no. 285. Brussels: National Bank of Belgium.

Crettenden A, Wright A and Skinner N (2014) Mothers caring for children and young people with developmental disabilities: intent to work, patterns of participation in paid employment and the experience of workplace flexibility. Community, Work \& Family 17(3): 244-267.

Debacker M (2007) De socio-economische positie van gezinnen met kinderen. In: Ghysels J and Debacker M (eds) Zorgen voor kinderen in Vlaanderen: een dagelijkse evenwichtsoefening? Leuven: Acco, 19-43.

Debacker M (2008) Care strategies among high- and low-skilled mothers: a world of difference? Work, Employment and Society 22(3): 527-545.

DeRigne L (2012) The employment and financial effects on families raising children with special health care needs: an examination of the evidence. Journal of Pediatric Health Care 26(4): 283-290.

Dhamoon RK (2011) Considerations on mainstreaming intersectionality. Political Research Quarterly 64(1): 230-243.

Emerson E (2012) Deprivation, ethnicity and the prevalence of intellectual and developmental disabilities. Journal of Epidemiology \& Community Health 66(3): 218-224.

Emerson E and Hatton C (2007) The socio-economic circumstances of children at risk of disability in Britain. Disability \& Society 22(6): 563-580.

Eurostat (2011) Migrants in Europe: A Statistical Portrait of the First and Second Generation. Luxembourg: Eurostat Statistical Books.

FAMIFED (2016) Een overzicht per entiteit van de kinderbijslag voor kinderen met een aandoening. Focusstudie 2016-3. Brussels: FAMIFED.

FAMIFED (2017) Aantal kinderen met een aandoening, volgens zelfredzaamheidsgraad en ernst van de gevolgen van de aandoening, op 31 December 2010. Available at: http://vlaanderen. famifed.be/nl/statistics/222?year=2010 (accessed 3 August 2017).

Fujiura GT and Yamaki K (2000) Trends in demography of childhood poverty and disability. Exceptional Children 66(2): 187-199.

Ghysels J and Van Lancker W (2011) The unequal benefits of activation: an analysis of the social distribution of family policy among families with young children. Journal of European Social Policy 21(5): 472-485.

Goldman N (2001) Social inequalities in health: Disentangling the underlying mechanisms. Annals of the New York Academy of Sciences 954(1): 118-139.

Gordon M, Rosenman L and Cuskelly M (2007) Constrained labour: maternal employment when children have disabilities. Journal of Applied Research in Intellectual Disabilities 20(3): 236-246.

Grammenos S (2013) European comparative data on Europe 2020 \& people with disabilities. Brussels: Centre for European Social and Economic Policy (CESEP ASBL) on behalf of Academic Network of European Disability Experts (ANED). 
Hancock A-M (2007) When multiplication doesn't equal quick addition: examining intersectionality as a research paradigm. Perspectives on Politics 5(1): 63-79.

Hauge LJ, Kornstad T, Nes RB, et al. (2013) The impact of a child's special health care needs on maternal work participation during early motherhood. Paediatric and Perinatal Epidemiology 27(4): 353-360.

Haveman M, Van Berkun G, Reijnders R, et al. (1997) Differences in service needs, time demands, and caregiving burden among parents of persons with mental retardation across the life cycle. Family Relations 46(4): 417-425.

Hemerijck A (2017) The Uses of Social Investment. Oxford: Oxford University Press.

Hemerijck A and Marx I (2010) Continental welfare at a crossroads: the choice between activation and minimum income protection in Belgium and the Netherlands. In: Palier B (ed.) A Long Goodbye to Bismarck? The Politics of Welfare Reform in Continental Europe. Amsterdam: Amsterdam University Press, 129-155.

Hvinden B (2003) The uncertain convergence of disability policies in Western Europe. Social Policy \& Administration 37(6): 609-624.

Kawa R, Saesmundsen E, Jónsdóttir SL, et al. (2016) European studies on prevalence and risk of autism spectrum disorders according to immigrant status - a review. The European Journal of Public Health 27(1): 101-110.

Konietzka D and Kreyenfeld M (2010) The growing educational divide in mothers' employment: an investigation based on the German micro-censuses 1976-2004. Work, Employment and Society 24(2): 260-278.

Kossek EE and Lautsch B (2018) Work-life flexibility for whom? Occupational status and worklife inequality in upper, middle, and lower level jobs. Academy of Management Annals 12(1): 5-36.

Leiter V, Wyngaarden Krauss M, Anderson B, et al. (2004) The consequences of caring: effects of mothering a child with special needs. Journal of Family Issues 25(3): 379-403.

Lindsay C, Greve B, Cabras I, et al. (2015) Assessing the evidence base on health, employability and the labour market: lessons for activation in the UK. Social Policy \& Administration 49(2): $143-160$.

Lu Z-H and Zuo A (2010) Effects of a child's disability on affected female's labour supply in Australia. Australian Economic Articles 49(3): 222-240.

McBride A, Hebson G and Holgate J (2015) Intersectionality: are we taking enough notice in the field of work and employment relations? Work, Employment and Society 29(2): $331-341$.

McCall L (2005) The complexity of intersectionality. Signs 30(3): 1771-1800.

Marin B, Prinz C and Queisser M (2004) Transforming Disability Welfare Policies: Towards Work and Equal Opportunities. Avebury: Ashgate.

Mooney S (2016) 'Nimble' intersectionality in employment research: a way to resolve methodological dilemmas. Work, Employment and Society 30(4): 708-718.

Nieuwenhuis R and Maldonado LC (2018) The Triple Bind of Single-parent Families: Resources, Employment and Policies to Improve Wellbeing. Bristol: Policy Press.

Nys A, Meeusen L and Corluy V (2016) Who cares? A counterfactual analysis of household work intensity in households with disabled family members. Social Indicators Research 128(2): $675-691$.

OECD (2010) Sickness, Disability and Work: Breaking the Barriers: A Synthesis of Findings across OECD Countries. Paris: OECD.

OECD (2012) Settling In: OECD Indicators of Immigrant Integration 2012. Paris: OECD. 
Olsson MB and Hwang CP (2006) Well-being, involvement in paid work and division of childcare in parents of children with intellectual disabilities in Sweden. Journal of Intellectual Disability Research 50(12): 963-969.

Owen L, Gordon M, Frederico M, et al. (2003) Listen to Us: Supporting Families with Children with Disabilities: Identifying Service Responses That Impact on the Risk of Family Breakdown. Melbourne, VIC: School of Social Work \& Social Policy, La Trobe University and Victorian Government Department of Human Services.

Pavolini E and Van Lancker W (2018) The Matthew effect in childcare use: a matter of policies or preferences? Journal of European Public Policy 25(6): 878-893.

Porterfield SL (2002) Work choices of mothers in families with children with disabilities. Journal of Marriage and Family 64(4): 972-981.

Powers ET (2001) New estimates of the impact of child disability on maternal employment. The American Economic Review 91(2): 135-139.

Powers ET (2003) Children's health and maternal work activity: estimates under alternative disability definitions. The Journal of Human Resources 38(3): 522-556.

Reichman NE, Corman H and Noonan K (2008) Impact of child disability on the family. Maternal and Child Health Journal 12(6): 679-683.

Risdal D and Singer GHS (2004) Marital adjustments in parents of children with disabilities: a historical review and meta-analysis. Research and Practice for Persons with Severe Disabilities 29(2): 95-103.

RKW (2013) De kinderbijslag voor kinderen met een aandoening: tien jaar na de hervorming. Focusstudie 2013-1. Brussels: RKW.

Roets G, Roose R, Claes L, et al. (2012) Reinventing the employable citizen: a perspective for social work. British Journal of Social Work 42(1): 94-110.

Sebrechts L and Breda J (2011) Kinderen met bijzondere behoeften en hun gezin. De kwetsbaarheid van deze gezinnen binnen het opkomend burgerschapsmodel (CSB Bericht). Antwerp: Herman Deleeck Centre for Social Policy.

Sebrechts L and Breda J (2012) Families of children with special needs in Flanders: their vulnerability within the citizenship paradigm. CSB Working Paper 12/01, January. Antwerp: Herman Deleeck Centre for Social Policy.

Shahtahmasebi S, Emerson E, Berridge D, et al. (2011) Child disability and the dynamics of family poverty, hardship and financial strain: evidence from the UK. Journal of Social Policy 40(4): 653-673.

Singh GK and Lin SC (2013) Marked ethnic, nativity, and socioeconomic disparities in disability and health insurance among US children and adults: the 2008-2010 American Community Survey. BioMed Research International 2013: 627412.

Stabile M and Allin S (2012) The economic costs of childhood disability. The Future of Children 22(1): 65-96.

Stahl JF and Schober PS (2018) Convergence or divergence? Educational discrepancies in workcare arrangements of mothers with young children in Germany. Work, Employment and Society 32(4): 629-649.

Tapia M and Alberti G (2019) Unpacking the category of migrant workers in trade union research: A multi-level approach to migrant intersectionalities. Work, Employment and Society 33(2): 314-325.

Van Lancker W (2013) Putting the child-centred investment strategy to the test: evidence for the EU27. European Journal of Social Security 15(1): 4-27.

Van Landeghem C, Breda J and Mestdagh K (2007) Zorgpatronen van kinderen met een handicap. In: Ghysels J and Debacker M (eds) Zorgen voor kinderen in Vlaanderen: een dagelijkse evenwichtsoefening? Leuven: Acco, 191-235. 
Van Oorschot W (1996) Modelling non-take-up: the interactive model of multi-level influences and the dynamic model of benefit receipt. In: Van Oorschot W (ed.) New Perspectives on the Non-Take-Up of Social Security Benefits. Tilburg: Tilburg University Press, 7-59.

Vinck J, Lebeer J and Van Lancker W (2019) Non-take up of the supplemental child benefit for children with a disability in Belgium: a mixed method approach. Social Policy \& Administration 53(3): 357-384.

Vornholt K, Villotti P, Muschalla B, et al. (2018) Disability and employment: overview and highlights. European Journal of Work and Organizational Psychology 27(1): 40-55.

Walby S (2007) Complexity theory, systems theory, and multiple intersecting social inequalities. Philosophy of the Social Sciences 37(4): 449-470.

Walby S, Armstrong J and Strid S (2012) Intersectionality: multiple inequalities in social theory. Sociology 46(2): 224-240.

Ward T and Özdemir E (2013) Measuing low work intensity - an analysis of the indicator. Improve Discussion Paper 13/09. Antwerp: Herman Deleeck Centre for Social Policy.

Warren JR (2009) Socioeconomic status and health across the life course: a test of the social causation and health selection hypotheses. Social Forces 87(4): 2125-2153.

Wasi N, van den Berg B and Buchmueller TC (2012) Heterogeneous effects of child disability on maternal labor supply: evidence from the 2000 US Census. Labour Economics 19(1): $139-154$.

Yuval-Davis N (2006) Intersectionality and feminist politics. European Journal of Women's Studies 13(3): 193-209.

Zhu A (2016) Maternal employment trajectories and caring for an infant or toddler with a disability. Applied Economics 48(48): 4606-4621.

Zuccotti CV and O'Reilly J (2018) Ethnicity, gender and household effects on becoming NEET: an intersectional analysis. Work, Employment and Society 33(3): 351-373.

Julie Vinck holds a master's degree in Social and Economic Sciences (University of Antwerp, 2012) and in Social Policy Analysis (KU Leuven, 2013). She is affiliated to the Herman Deleeck Centre for Social Policy at the University of Antwerp and works as a PhD fellow of the Research Foundation Flanders (FWO). The topic of her research concerns 'The poverty-care nexus in the social investment state: an empirical investigation of childhood disability, child poverty and parental employment in Belgium'.

Wim Van Lancker is an Assistant Professor in Social Work and Social Policy affiliated with the Centre for Sociological Research (CESO) at the University of Leuven. His research is focused on the design and effectiveness of social policy measures in reducing poverty and inequality, with a particular focus on childhood inequality.

Date submitted October 2018

Date accepted July 2019 


\section{Appendix I}

Descriptive information on dependent, independent and control variables for disabled and nondisabled children in Belgium, 2010.

\begin{tabular}{|c|c|c|}
\hline $0-20 y$ & Disabled & Non-disabled \\
\hline \multicolumn{3}{|l|}{ Dependent variable } \\
\hline \multicolumn{3}{|l|}{ Household work intensity } \\
\hline Very low work intensity $(0-0.2)$ & $19 \%$ & $10 \%$ \\
\hline Low work intensity $(0.2-0.45)$ & $5 \%$ & $3 \%$ \\
\hline Medium work intensity $(0.45-0.55)$ & $11 \%$ & $7 \%$ \\
\hline High work intensity $(0.55-0.85)$ & $23 \%$ & $21 \%$ \\
\hline Very high work intensity $(0.85-\mathrm{I})$ & $42 \%$ & $59 \%$ \\
\hline \multicolumn{3}{|l|}{ Independent variables } \\
\hline Disability prevalence & $2 \%$ & $98 \%$ \\
\hline \multicolumn{3}{|l|}{ Severity of disability (points) } \\
\hline $1-5$ & $\begin{array}{l}\text { No } \\
\text { observations }\end{array}$ & $\mathrm{n} / \mathrm{a}$ \\
\hline $6-10$ & $60 \%$ & $\mathrm{n} / \mathrm{a}$ \\
\hline $11-15$ & $24 \%$ & $\mathrm{n} / \mathrm{a}$ \\
\hline $16-20$ & $9 \%$ & $\mathrm{n} / \mathrm{a}$ \\
\hline $21-25$ & $5 \%$ & $\mathrm{n} / \mathrm{a}$ \\
\hline $26-30$ & $1 \%$ & $\mathrm{n} / \mathrm{a}$ \\
\hline $31-36$ & $0.1 \%$ & $\mathrm{n} / \mathrm{a}$ \\
\hline \multicolumn{3}{|l|}{ Household type } \\
\hline Two-parent household & $70 \%$ & $78 \%$ \\
\hline Single mother household & $27 \%$ & $19 \%$ \\
\hline Single father household & $4 \%$ & $3 \%$ \\
\hline \multicolumn{3}{|l|}{ Country of birth parents } \\
\hline At least one parent born in Belgium & $91 \%$ & $91 \%$ \\
\hline At least one parent born in other EU27 country & $2 \%$ & $3 \%$ \\
\hline Both parents born in non-EU27 countries & $7 \%$ & $6 \%$ \\
\hline \multicolumn{3}{|l|}{ Parental education (highest level) } \\
\hline Low-skilled & $24 \%$ & $15 \%$ \\
\hline Medium-skilled & $41 \%$ & $35 \%$ \\
\hline High-skilled & $35 \%$ & $50 \%$ \\
\hline \multicolumn{3}{|l|}{ Other disabled household member(s) } \\
\hline At least one of the siblings (non-exclusive category) & $9 \%$ & $\mathrm{n} / \mathrm{a}$ \\
\hline At least one of the parents (non-exclusive category) & $8 \%$ & $2 \%$ \\
\hline At least one of the other adults (non-exclusive category) & $1 \%$ & $1 \%$ \\
\hline None (exclusive category) & $83 \%$ & $97 \%$ \\
\hline \multicolumn{3}{|l|}{ Control variables } \\
\hline \multicolumn{3}{|l|}{ Age child } \\
\hline $0-3 y$ & $9 \%$ & $30 \%$ \\
\hline $4-5 y$ & $9 \%$ & $11 \%$ \\
\hline $6-11 y$ & $40 \%$ & $28 \%$ \\
\hline
\end{tabular}


Appendix I. (Continued)

\begin{tabular}{lll}
$0-20 y$ & Disabled & Non-disabled \\
\hline I2-I7y & $36 \%$ & $24 \%$ \\
I8-20y & $6 \%$ & $8 \%$ \\
Sex child & & \\
Male & $64 \%$ & $51 \%$ \\
Female & $36 \%$ & $49 \%$ \\
Region of residence & & \\
Brussels & $6 \%$ & $8 \%$ \\
Flanders & $61 \%$ & $59 \%$ \\
Wallonia & $33 \%$ & $33 \%$ \\
Age mother (mean) & 40.2 & 39.8 \\
Number of siblings (mean) & 1.2 & 1.1
\end{tabular}

Source: own calculations on DWH LM \& SP, year 2010 and Census, year $201 \mathrm{I}$.

Note: all proportions differ significantly $(p<0.05)$ between disabled and non-disabled children, except for the share of children living in Wallonia, with at least one parent born in Belgium or in another EU27 country. 


\section{Appendix 2}

\section{Sensitivity check: Regression results without applying the population weight}

Table A2. I. Logistic regressions on having a disabled child, without population weight, odds ratios, Belgium, 2010.

\begin{tabular}{|c|c|c|}
\hline $0-20 y$ & Model I & Model 2 \\
\hline Constant & $\begin{array}{l}0.168^{* * * *} \\
(0.006)\end{array}$ & $\begin{array}{l}0.167^{* * * * *} \\
(0.006)\end{array}$ \\
\hline \multicolumn{3}{|l|}{ Social categories } \\
\hline Single parent & $\begin{array}{l}1.165^{* * * *} \\
(0.033)\end{array}$ & $\begin{array}{l}1.160 \text { **** } \\
(0.033)\end{array}$ \\
\hline \multicolumn{3}{|l|}{ Country of birth parent (Belgium ref.) } \\
\hline EU27 & $\begin{array}{l}0.728^{* * * *} \\
(0.055)\end{array}$ & $\begin{array}{l}0.832 \\
(0.119)\end{array}$ \\
\hline Non-EU27 & $\begin{array}{l}0.994 \\
(0.048)\end{array}$ & $\begin{array}{l}\text { I.230* } \\
(0.116)\end{array}$ \\
\hline \multicolumn{3}{|l|}{ Parental education (High-skilled ref.) } \\
\hline Medium-skilled & $\begin{array}{l}\text { I.456**** } \\
(0.037)\end{array}$ & $\begin{array}{l}1.469 * * * * \\
(0.039)\end{array}$ \\
\hline Low-skilled & $\begin{array}{l}1.674^{* * * *} \\
(0.058)\end{array}$ & $\begin{array}{l}1.748^{* * * *} \\
(0.066)\end{array}$ \\
\hline \multicolumn{3}{|c|}{ Other disabled household member(s) (None ref.) } \\
\hline Yes, at least one & $\begin{array}{l}5.819 * * * * \\
(0.298)\end{array}$ & $\begin{array}{l}5.795 \text { **** } \\
(0.297)\end{array}$ \\
\hline \multicolumn{3}{|l|}{ Interaction } \\
\hline \multicolumn{3}{|c|}{ Country of birth parents $x$ Parental education } \\
\hline EU27 x Medium-skilled & & $\begin{array}{l}0.787 \\
(0.157)\end{array}$ \\
\hline EU27 x Low-skilled & & $\begin{array}{l}0.845 \\
(0.156)\end{array}$ \\
\hline Non-EU27 x Medium-skilled & & $\begin{array}{l}0.871 \\
(0.113)\end{array}$ \\
\hline Non-EU27 x Low-skilled & & $\begin{array}{l}0.68 I^{* * *} \\
(0.08 I)\end{array}$ \\
\hline \multicolumn{3}{|l|}{ Child characteristics } \\
\hline \multicolumn{3}{|l|}{ Age (0-3y ref.) } \\
\hline $4-5 y$ & $\begin{array}{l}2.39 I^{* * * *} \\
(0.1111)\end{array}$ & $\begin{array}{l}2.392^{* * * * *} \\
(0.1111)\end{array}$ \\
\hline $6-11 y$ & $\begin{array}{l}4.158^{* * * *} \\
(0.145)\end{array}$ & $\begin{array}{l}4.156^{* * * * *} \\
(0.145)\end{array}$ \\
\hline $12-17 y$ & $\begin{array}{l}4.314^{* * * * *} \\
(0.155)\end{array}$ & $\begin{array}{l}4.309 * * * * \\
(0.155)\end{array}$ \\
\hline $18-20 y$ & $\begin{array}{l}1.926^{* * *} \\
(0.101)\end{array}$ & $\begin{array}{l}1.919^{* * * *} \\
(0.100)\end{array}$ \\
\hline Male & $\begin{array}{l}1.605^{* * * *} \\
(0.038)\end{array}$ & $\begin{array}{l}1.604^{* * * *} \\
(0.038)\end{array}$ \\
\hline \multicolumn{3}{|l|}{ Model fit } \\
\hline Log likelihood & -21700.03 & -21693.61 \\
\hline Pseudo $\mathrm{R}^{2}$ & 0.1159 & 0.1162 \\
\hline Prob $>\mathrm{Chi}^{2}$ & 0.000 & 0.000 \\
\hline Likelihood-ratio test compared to M-I & & 12.83 \\
\hline Prob $>\mathrm{Chi}^{2}$ compared to $\mathrm{M}-\mathrm{I}$ & & 0.012 \\
\hline $\mathbf{N}$ & 35415 & 35415 \\
\hline
\end{tabular}

Source: own calculations on DWH LM\&SP, year 2010 and Census, year 201I.

Notes: no disability is base outcome. Standard errors in parentheses. * $p<0.05$; ** $p<0.01$; *** $p<0.001$.

Odds ratio's smaller than one indicate a lower risk to have a disability, odds ratio's larger than one indicate a higher risk, compared to the reference category. 
Table A2.2. Stepwise multivariate regression on household work intensity, without population weight, Belgium, 2010.

\begin{tabular}{|c|c|c|c|}
\hline Belgium (0-20y) & Model I & Model 2 & Model 3 \\
\hline Constant & $\begin{array}{l}0.832^{\text {**** }} \\
(0.005)\end{array}$ & $\begin{array}{l}0.940 * * * \\
(0.004)\end{array}$ & $\begin{array}{l}0.936 \text { *** } \\
(0.005)\end{array}$ \\
\hline \multicolumn{4}{|l|}{ Disability } \\
\hline Severity of disability & $\begin{array}{l}-0.008^{* * * *} \\
(0.000)\end{array}$ & $\begin{array}{l}-0.005^{*} * * * \\
(0.000)\end{array}$ & $\begin{array}{l}-0.004 * * * \\
(0.001)\end{array}$ \\
\hline \multicolumn{4}{|l|}{ Social categories } \\
\hline Single parent & & $\begin{array}{l}-0.258 * * * \\
(0.003)\end{array}$ & $\begin{array}{l}-0.247 * * * \\
(0.004)\end{array}$ \\
\hline \multicolumn{4}{|l|}{ Country of birth parents (Belgium ref.) } \\
\hline EU27 & & $\begin{array}{l}-0.030 * * \\
(0.009)\end{array}$ & $\begin{array}{l}-0.024 * \\
(0.011)\end{array}$ \\
\hline Non-EU27 & & $\begin{array}{l}-0.136 * * * \\
(0.006)\end{array}$ & $\begin{array}{l}-0.136^{* * *} \\
(0.007)\end{array}$ \\
\hline \multicolumn{4}{|l|}{ Parental education (High-skilled ref.) } \\
\hline Medium-skilled & & $\begin{array}{l}-0.128^{* * * *} \\
(0.003)\end{array}$ & $\begin{array}{l}-0.120 * * * \\
(0.004)\end{array}$ \\
\hline Low-skilled & & $\begin{array}{l}-0.261 \text { *** } \\
(0.004)\end{array}$ & $\begin{array}{l}-0.261 \text { *** } \\
(0.005)\end{array}$ \\
\hline \multicolumn{4}{|c|}{ Other disabled HH members, excluding siblings (None ref.) } \\
\hline Parent(s) & & $\begin{array}{l}-0.274 * * * \\
(0.006)\end{array}$ & $\begin{array}{l}-0.284^{* * *} \\
(0.009)\end{array}$ \\
\hline Other adult(s) & & $\begin{array}{l}-0.136 * * * \\
(0.014)\end{array}$ & $\begin{array}{l}-0.164^{* * *} \\
(0.020)\end{array}$ \\
\hline \multicolumn{4}{|l|}{ Interaction $x$ Severity of disability } \\
\hline Single parent $\times$ Severity of disability & & & $\begin{array}{l}-0.004 * * * \\
(0.001)\end{array}$ \\
\hline \multicolumn{4}{|l|}{ Country of birth parents (Belgium ref.) } \\
\hline EU27 x Severity of disability & & & $\begin{array}{l}-0.002 \\
(0.002)\end{array}$ \\
\hline Non-EU27 x Severity of disability & & & $\begin{array}{c}0.000 \\
(0.001)\end{array}$ \\
\hline \multicolumn{4}{|l|}{ Parental education (High-skilled ref.) } \\
\hline Medium-skilled $x$ Severity of disability & & & $\begin{array}{l}-0.003 * * * \\
(0.001)\end{array}$ \\
\hline Low-skilled $x$ Severity of disability & & & $\begin{array}{l}-0.001 \\
(0.001)\end{array}$ \\
\hline \multicolumn{4}{|l|}{ Other disabled HH members } \\
\hline Other adult(s) $\times$ Severity of disability & & & $\begin{array}{c}0.006 * \\
(0.003)\end{array}$ \\
\hline Parent(s) $\times$ Severity of disability & & & $\begin{array}{c}0.003 \\
(0.002)\end{array}$ \\
\hline Sibling $(s) \times$ Severity of disability & & $\begin{array}{l}-0.002^{*} \\
(0.001)\end{array}$ & $\begin{array}{l}-0.002 * \\
(0.001)\end{array}$ \\
\hline
\end{tabular}


Table A2.2. (Continued)

\begin{tabular}{|c|c|c|c|}
\hline Belgium $(0-20 y)$ & Model I & Model 2 & Model 3 \\
\hline \multicolumn{4}{|l|}{ Age of the child (0-3y ref.) } \\
\hline $4-5 y \times$ Severity of disability & & & $\begin{array}{l}-0.002 \\
(0.001)\end{array}$ \\
\hline $6-11 y \times$ Severity of disability & & & $\begin{array}{l}-0.000 \\
(0.001)\end{array}$ \\
\hline $12-17 y \times$ Severity of disability & & & $\begin{array}{c}0.001 \\
(0.001)\end{array}$ \\
\hline I8-20y $\times$ Severity of disability & & & $\begin{array}{c}0.003 \\
(0.001)\end{array}$ \\
\hline \multicolumn{4}{|l|}{ Control variables } \\
\hline \multicolumn{4}{|l|}{ Age child (0-3y ref.) } \\
\hline $4-5 y$ & $\begin{array}{l}0.024 * * \\
(0.007)\end{array}$ & $\begin{array}{l}0.040 * * * \\
(0.006)\end{array}$ & $\begin{array}{l}0.045^{* * * *} \\
(0.006)\end{array}$ \\
\hline $6-11 y$ & $\begin{array}{c}0.012^{*} \\
(0.005)\end{array}$ & $\begin{array}{l}0.057 * * * \\
(0.004)\end{array}$ & $\begin{array}{l}0.058^{\text {**** }} \\
(0.005)\end{array}$ \\
\hline $12-17 y$ & $\begin{array}{l}0.030 \text { **** } \\
(0.006)\end{array}$ & $\begin{array}{l}0.085 * * * \\
(0.005)\end{array}$ & $\begin{array}{l}0.08 I^{\text {**** }} \\
(0.005)\end{array}$ \\
\hline $18-20 y$ & $\begin{array}{c}0.007 \\
(0.009)\end{array}$ & $\begin{array}{l}0.072 * * * \\
(0.007)\end{array}$ & $\begin{array}{l}0.063^{* * * *} \\
(0.008)\end{array}$ \\
\hline Male & $\begin{array}{l}-0.014^{* * * *} \\
(0.004)\end{array}$ & $\begin{array}{l}-0.006 \\
(0.003)\end{array}$ & $\begin{array}{l}-0.006 \\
(0.003)\end{array}$ \\
\hline \multicolumn{4}{|l|}{ Region of residence (Flanders ref.) } \\
\hline Brussels & $\begin{array}{l}-0.200 * * * \\
(0.007)\end{array}$ & $\begin{array}{l}-0.074 * * * \\
(0.006)\end{array}$ & $\begin{array}{l}-0.073 \text { *** } \\
(0.006)\end{array}$ \\
\hline Wallonia & $\begin{array}{l}-0.149 \text { **** } \\
(0.004)\end{array}$ & $\begin{array}{l}-0.080 * * * * \\
(0.003)\end{array}$ & $\begin{array}{l}-0.080^{* * * *} \\
(0.003)\end{array}$ \\
\hline Age mother (centred around the mean) & $\begin{array}{l}-0.005 * * * \\
(0.000)\end{array}$ & $\begin{array}{l}-0.003 * * * \\
(0.000)\end{array}$ & $\begin{array}{l}-0.032^{* * * *} \\
(0.001)\end{array}$ \\
\hline Number of siblings $(<2 \mathrm{ly})$ & $\begin{array}{l}-0.034 * * * \\
(0.002)\end{array}$ & $\begin{array}{l}-0.031 \text { *** } \\
(0.001)\end{array}$ & $\begin{array}{l}-0.032^{* * * *} \\
(0.001)\end{array}$ \\
\hline \multicolumn{4}{|l|}{ Model fit } \\
\hline Log likelihood & -10476.16 & -2806.44 & -2774.34 \\
\hline $\mathrm{R}^{2}$ & 0.0899 & 0.4100 & 0.4110 \\
\hline Likelihood-ratio test compared to M-I & & 15339.44 & 64.19 \\
\hline Prob $>\mathrm{Chi}^{2}$ compared to $\mathrm{M}-\mathrm{I}$ & & 0.000 & 0.000 \\
\hline $\mathbf{N}$ & 35415 & 35415 & $354 I 5$ \\
\hline
\end{tabular}

Source: own calculations based on DWH LM\&SP, year 2010 and Census, year $201 \mathrm{I}$.

Notes: standard errors in parentheses. ${ }^{*} \mathrm{p}<0.05$, ${ }^{* *} \mathrm{p}<0.0 \mathrm{I}, * * * \mathrm{p}<0.001$. 


\section{Appendix 3}

Sensitivity check: stepwise multivariate regression on work intensity, excluding extended families, Belgium, 2010.

\begin{tabular}{|c|c|c|c|}
\hline Belgium (0-20y) & Model I & Model 2 & Model 3 \\
\hline Constant & $\begin{array}{l}0.884^{* * * *} \\
(0.008)\end{array}$ & $\begin{array}{l}0.949 * * * \\
(0.006)\end{array}$ & $\begin{array}{l}0.949 * * * \\
(0.006)\end{array}$ \\
\hline \multicolumn{4}{|l|}{ Disability } \\
\hline Severity of disability & $\begin{array}{l}-0.012 * * * \\
(0.000)\end{array}$ & $\begin{array}{l}-0.007 * * * * \\
(0.000)\end{array}$ & $\begin{array}{l}-0.003 * * \\
(0.001)\end{array}$ \\
\hline \multicolumn{4}{|l|}{ Social categories } \\
\hline Single parent & & $\begin{array}{l}-0.23 I^{* * * *} \\
(0.007)\end{array}$ & $\begin{array}{l}-0.230 * * * \\
(0.007)\end{array}$ \\
\hline \multicolumn{4}{|l|}{ Country of birth parents (Belgium ref.) } \\
\hline EU27 & & $\begin{array}{l}-0.033 \\
(0.017)\end{array}$ & $\begin{array}{l}-0.033 \\
(0.017)\end{array}$ \\
\hline Non-EU27 & & $\begin{array}{l}-0.142^{* * * *} \\
(0.012)\end{array}$ & $\begin{array}{l}-0.142 * * * \\
(0.012)\end{array}$ \\
\hline \multicolumn{4}{|l|}{ Parental education (High-skilled ref.) } \\
\hline Medium-skilled & & $\begin{array}{l}-0.106 * * * \\
(0.004)\end{array}$ & $\begin{array}{l}-0.106 * * * \\
(0.004)\end{array}$ \\
\hline Low-skilled & & $\begin{array}{l}-0.244^{* * * *} \\
(0.008)\end{array}$ & $\begin{array}{l}-0.243^{* * * *} \\
(0.008)\end{array}$ \\
\hline \multicolumn{4}{|c|}{ Other disabled HH members, excluding siblings (None ref.) } \\
\hline Parent(s) & & $\begin{array}{l}-0.287^{* * * *} \\
(0.017)\end{array}$ & $\begin{array}{l}-0.287^{* * *} \\
(0.018)\end{array}$ \\
\hline Other adult(s) & & $\begin{array}{l}-0.145^{* *} \\
(0.049)\end{array}$ & $\begin{array}{l}-0.146 * * \\
(0.050)\end{array}$ \\
\hline \multicolumn{4}{|l|}{ Interaction $x$ Severity of disability } \\
\hline Single parent $x$ Severity of disability & & & $\begin{array}{l}-0.006 \text { *** } \\
(0.001)\end{array}$ \\
\hline \multicolumn{4}{|l|}{ Country of birth parents (Belgium ref.) } \\
\hline EU27 $\times$ Severity of disability & & & $\begin{array}{l}-0.001 \\
(0.003)\end{array}$ \\
\hline Non-EU27 x Severity of disability & & & $\begin{array}{l}0.001 \\
(0.002)\end{array}$ \\
\hline \multicolumn{4}{|l|}{ Parental education (High-skilled ref.) } \\
\hline Medium-skilled $x$ Severity of disability & & & $\begin{array}{l}-0.004 * * * \\
(0.001)\end{array}$ \\
\hline Low-skilled x Severity of disability & & & $\begin{array}{l}-0.003^{*} \\
(0.001)\end{array}$ \\
\hline \multicolumn{4}{|l|}{ Other disabled HH members } \\
\hline Other adult(s) $\times$ Severity of disability & & & $\begin{array}{l}0.005 \\
(0.007)\end{array}$ \\
\hline
\end{tabular}


Appendix 3. (Continued)

Belgium (0-20y)

Model I

Model 2

Model 3

Parent(s) $\times$ Severity of disability

0.001

Sibling(s) $\times$ Severity of disability

$(0.003)$

$-0.004 * * \quad-0.003 *$

$(0.001)$

$(0.001)$

Age of the child (0-3y ref.)

4-5y $x$ Severity of disability

$-0.003 *$

(0.00I)

6-IIy $\times$ Severity of disability

$-0.002 *$

$(0.001)$

12-17y x Severity of disability

$-0.001$

$(0.001)$

18-20y $x$ Severity of disability

0.001

$(0.002)$

Control variables

Age child (0-3y ref.)

4-5y

6-IIy

$12-17 y$

$18-20 y$

Male

$\begin{array}{lll}0.029 \text { *** } & 0.052^{* * * *} & 0.052^{* * * *} \\ (0.008) & (0.006) & (0.006) \\ 0.021^{* * *} & 0.063^{* * *} & 0.063^{* * *} \\ (0.007) & (0.006) & (0.006) \\ 0.005 & 0.068 * * * & 0.068 * * * \\ (0.009) & (0.008) & (0.008) \\ -0.071 * * * & 0.024 & 0.024 \\ (0.015) & (0.013) & (0.013) \\ -0.002 & 0.001 & 0.001 \\ (0.004) & (0.004) & (0.004)\end{array}$

Region of residence (Flanders ref.)

Brussels

$-0.194 * * *$

$-0.075^{* * * *}$

$-0.075^{* * * *}$

$(0.011)$

Wallonia

$-0.129 * * * *$

$(0.009)$

$(0.009)$

(0.005)

$-0.075^{* * * *}$

$-0.075^{* * * *}$

$(0.004)$

(0.004)

$0.002 * *$

0.000

0.000

$(0.001)$

$(0.000)$

$(0.000)$

-0.034 **⿰㇇⿰亅⿱丿丶丶

$-0.031 * * *$

-0.031 I***

(0.003)

$(0.002)$

$(0.002)$

\section{Model fit}

Log likelihood

$\begin{array}{lll}-5433.71 & 468.89 & 473.32 \\ 0.0741 & 0.3597 & 0.3599 \\ & 11805.20 & 8.86 \\ & 0.000 & 0.6347 \\ 31999 & 31999 & 31999\end{array}$

$\mathrm{R}^{2}$

Likelihood-ratio test compared to M-I

Prob $>\mathrm{Chi}^{2}$ compared to $\mathrm{M}-\mathrm{I}$

N

31999

Source: own calculations based on DWH LM\&SP, year 2010 and Census, year 2011 .

Notes: Robust standard errors in parentheses. ${ }^{*} \mathrm{p}<0.05$, ** $\mathrm{p}<0.01$, $* * * \mathrm{p}<0.001$. 


\section{Appendix 4}

Sensitivity check: Stepwise multivariate regression for mothers and fathers separately, Belgium, 2010

Table A4.I. Stepwise multivariate regression on maternal employment status (yes/no), Belgium, 2010.

\begin{tabular}{|c|c|c|c|}
\hline Belgium (0-20y) & Model I & Model 2 & Model 3 \\
\hline Constant & $\begin{array}{l}0.866 * * * \\
(0.008)\end{array}$ & $\begin{array}{l}0.950 * * * \\
(0.008)\end{array}$ & $\begin{array}{l}0.950 \text { **** } \\
(0.008)\end{array}$ \\
\hline \multicolumn{4}{|l|}{ Disability } \\
\hline Severity of disability & $\begin{array}{l}-0.014^{* * * *} \\
(0.001)\end{array}$ & $\begin{array}{l}-0.009 * * * \\
(0.001)\end{array}$ & $\begin{array}{l}-0.004 * * \\
(0.001)\end{array}$ \\
\hline \multicolumn{4}{|l|}{ Social categories } \\
\hline \multicolumn{4}{|l|}{ Single parent (No ref.) } \\
\hline Yes & & $\begin{array}{l}-0.183 * * * \\
(0.008)\end{array}$ & 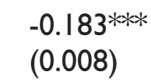 \\
\hline \multicolumn{4}{|l|}{ Country of birth parents (Belgium ref.) } \\
\hline EU27 & & $\begin{array}{l}-0.013 \\
(0.020)\end{array}$ & $\begin{array}{l}-0.013 \\
(0.020)\end{array}$ \\
\hline Non-EU27 & & $\begin{array}{l}-0.122 * * * \\
(0.015)\end{array}$ & $\begin{array}{l}-0.122 * * * * \\
(0.015)\end{array}$ \\
\hline \multicolumn{4}{|l|}{ Parental education (High-skilled ref.) } \\
\hline Medium-skilled & & $\begin{array}{l}-0.106 * * * \\
(0.005)\end{array}$ & $\begin{array}{l}-0.105^{* * * *} \\
(0.005)\end{array}$ \\
\hline Low-skilled & & $\begin{array}{l}-0.227^{* * *} \\
(0.010)\end{array}$ & $\begin{array}{l}-0.227^{* * * *} \\
(0.010)\end{array}$ \\
\hline \multicolumn{4}{|c|}{ Other disabled HH members, excluding siblings (None ref.) } \\
\hline Parent(s) & & $\begin{array}{l}-0.376 * * * \\
(0.022)\end{array}$ & $\begin{array}{l}-0.376 \text { **** } \\
(0.023)\end{array}$ \\
\hline Other adult(s) & & $\begin{array}{l}-0.111 \text { ** } \\
(0.040)\end{array}$ & $\begin{array}{l}-0.112^{* *} \\
(0.042)\end{array}$ \\
\hline \multicolumn{4}{|l|}{ Interaction $x$ Severity of disability } \\
\hline Single parent $\times$ Severity of disability & & & $\begin{array}{l}-0.002 \\
(0.001)\end{array}$ \\
\hline \multicolumn{4}{|l|}{ Country of birth parents (Belgium ref.) } \\
\hline EU27 $\times$ Severity of disability & & & $\begin{array}{c}0.001 \\
(0.004)\end{array}$ \\
\hline Non-EU27 x Severity of disability & & & $\begin{array}{l}-0.001 \\
(0.002)\end{array}$ \\
\hline \multicolumn{4}{|l|}{ Parental education (High-skilled ref.) } \\
\hline Medium-skilled $x$ Severity of disability & & & $\begin{array}{l}-0.006 \text { *** } \\
(0.001)\end{array}$ \\
\hline Low-skilled $x$ Severity of disability & & & $\begin{array}{l}-0.007^{* * * *} \\
(0.002)\end{array}$ \\
\hline
\end{tabular}


Table A4.I. (Continued)

\begin{tabular}{|c|c|c|c|}
\hline Belgium (0-20y) & Model I & Model 2 & Model 3 \\
\hline \multicolumn{4}{|l|}{ Other disabled HH members } \\
\hline Other adult(s) $\times$ Severity of disability & & & $\begin{array}{l}0.003 \\
(0.006)\end{array}$ \\
\hline Parent(s) $\times$ Severity of disability & & & $\begin{array}{l}0.002 \\
(0.003)\end{array}$ \\
\hline Sibling $(s) \times$ Severity of disability & & $\begin{array}{l}-0.007 * * * * \\
(0.002)\end{array}$ & $\begin{array}{l}-0.006 \text { **** } \\
(0.002)\end{array}$ \\
\hline \multicolumn{4}{|l|}{ Age of the child (0-3y ref.) } \\
\hline $4-5 y \times$ Severity of disability & & & $\begin{array}{l}-0.002 \\
(0.002)\end{array}$ \\
\hline 6-IIy x Severity of disability & & & $\begin{array}{l}-0.002 \\
(0.002)\end{array}$ \\
\hline I2-17y x Severity of disability & & & $\begin{array}{l}0.001 \\
(0.002)\end{array}$ \\
\hline 18-20y $\times$ Severity of disability & & & $\begin{array}{c}0.003 \\
(0.002)\end{array}$ \\
\hline \multicolumn{4}{|l|}{ Control variables } \\
\hline \multicolumn{4}{|l|}{ Age child (0-3y ref.) } \\
\hline $4-5 y$ & $\begin{array}{l}0.076 * * * \\
(0.009)\end{array}$ & $\begin{array}{l}0.083 * * * \\
(0.008)\end{array}$ & $\begin{array}{l}0.083^{* * *} \\
(0.008)\end{array}$ \\
\hline $6-11 y$ & $\begin{array}{l}0.099 * * * \\
(0.008)\end{array}$ & $\begin{array}{l}0.113^{* * * *} \\
(0.007)\end{array}$ & $\begin{array}{l}0.114 * * * \\
(0.007)\end{array}$ \\
\hline $12-17 y$ & $\begin{array}{l}0.013 * * * \\
(0.010)\end{array}$ & $\begin{array}{l}0.146 * * * \\
(0.009)\end{array}$ & $\begin{array}{l}0.145^{* * *} \\
(0.009)\end{array}$ \\
\hline $18-20 y$ & $\begin{array}{l}0.105 * * * \\
(0.015)\end{array}$ & $\begin{array}{l}0.142^{* * * *} \\
(0.013)\end{array}$ & $\begin{array}{l}0.142 * * * \\
(0.013)\end{array}$ \\
\hline Male & $\begin{array}{c}0.003 \\
(0.005)\end{array}$ & $\begin{array}{l}0.005 \\
(0.005)\end{array}$ & $\begin{array}{c}0.005 \\
(0.005)\end{array}$ \\
\hline \multicolumn{4}{|l|}{ Region of residence (Flanders ref.) } \\
\hline Brussels & $\begin{array}{l}-0.208 * * * \\
(0.013)\end{array}$ & $\begin{array}{l}-0.110^{* * *} \\
(0.012)\end{array}$ & $\begin{array}{l}-0.110 * * * \\
(0.012)\end{array}$ \\
\hline Wallonia & $\begin{array}{l}-0.124 * * * \\
(0.006)\end{array}$ & $\begin{array}{l}-0.080^{* * * *} \\
(0.005)\end{array}$ & $\begin{array}{l}-0.080 * * * \\
(0.005)\end{array}$ \\
\hline Age mother (centred around the mean) & $\begin{array}{l}-0.006 * * * \\
(0.001)\end{array}$ & $\begin{array}{l}-0.004 * * * \\
(0.001)\end{array}$ & $\begin{array}{l}-0.004 * * * \\
(0.001)\end{array}$ \\
\hline Number of siblings $(<21 y)$ & $\begin{array}{l}-0.031 * * * \\
(0.003)\end{array}$ & $\begin{array}{l}-0.027 * * * \\
(0.003)\end{array}$ & $\begin{array}{l}-0.027^{* * *} \\
(0.003)\end{array}$ \\
\hline \multicolumn{4}{|l|}{ Model fit } \\
\hline Log likelihood & $-|2| 86.3 \mid$ & -8788.78 & -8785.67 \\
\hline $\mathrm{R}^{2}$ & 0.0686 & 0.2364 & 0.2365 \\
\hline Likelihood-ratio test compared to M-I & & 6795.05 & 6.23 \\
\hline Prob $>\mathrm{Chi}^{2}$ compared to $\mathrm{M}-\mathrm{I}$ & & 0.000 & 0.8573 \\
\hline $\mathbf{N}$ & 34210 & 34210 & 34210 \\
\hline
\end{tabular}

Source: own calculations based on DWH LM\&SP, year 2010 and Census, year 2011.

Notes: robust standard errors in parentheses. ${ }^{*} \mathrm{p}<0.05$, ${ }^{*} \mathrm{p}<0.01$, $* * * \mathrm{p}<0.00 \mathrm{I}$. 
Table A4.2. Stepwise multivariate regression on paternal employment status (yes/no), Belgium, 2010.

\begin{tabular}{|c|c|c|c|}
\hline Belgium (0-20y) & Model I & Model 2 & Model 3 \\
\hline Constant & $\begin{array}{l}0.913^{* * * *} \\
(0.007)\end{array}$ & $\begin{array}{l}0.942 * * * \\
(0.007)\end{array}$ & $\begin{array}{l}0.942 * * * * \\
(0.007)\end{array}$ \\
\hline \multicolumn{4}{|l|}{ Disability } \\
\hline Severity of disability & $\begin{array}{l}-0.006 \text { *** } \\
(0.000)\end{array}$ & $\begin{array}{l}-0.004 * * * \\
(0.000)\end{array}$ & $\begin{array}{c}0.001 \\
(0.001)\end{array}$ \\
\hline \multicolumn{4}{|l|}{ Social categories } \\
\hline Single parent & & $\begin{array}{l}-0.091 \text { *** } \\
(0.015)\end{array}$ & $\begin{array}{l}-0.089 * * * * \\
(0.015)\end{array}$ \\
\hline \multicolumn{4}{|l|}{ Country of birth parents (Belgium ref.) } \\
\hline EU27 & & $\begin{array}{l}-0.003 \\
(0.019)\end{array}$ & $\begin{array}{l}-0.003 \\
(0.019)\end{array}$ \\
\hline Non-EU27 & & $\begin{array}{l}-0.100 * * * \\
(0.015)\end{array}$ & $\begin{array}{l}-0.100 * * * \\
(0.016)\end{array}$ \\
\hline \multicolumn{4}{|l|}{ Parental education (High-skilled ref.) } \\
\hline Medium-skilled & & $\begin{array}{l}-0.034 * * * \\
(0.004)\end{array}$ & $\begin{array}{l}-0.034 * * * * \\
(0.004)\end{array}$ \\
\hline Low-skilled & & $\begin{array}{l}-0.116^{* * *} \\
(0.009)\end{array}$ & $\begin{array}{l}-0.115^{* * *} \\
(0.009)\end{array}$ \\
\hline \multicolumn{4}{|c|}{ Other disabled HH members, excluding siblings (None ref.) } \\
\hline Parent(s) & & $\begin{array}{l}-0.325 * * * \\
(0.025)\end{array}$ & 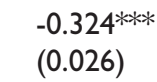 \\
\hline Other adult(s) & & $\begin{array}{l}-0.048 \\
(0.036)\end{array}$ & $\begin{array}{l}-0.048 \\
(0.037)\end{array}$ \\
\hline \multicolumn{4}{|l|}{ Interaction $x$ Severity of disability } \\
\hline Single parent $\times$ Severity of disability & & & $\begin{array}{l}-0.016 \text { **** } \\
(0.002)\end{array}$ \\
\hline \multicolumn{4}{|l|}{ Country of birth parents (Belgium ref.) } \\
\hline EU27 $\times$ Severity of disability & & & $\begin{array}{l}-0.001 \\
(0.004)\end{array}$ \\
\hline Non-EU27 x Severity of disability & & & $\begin{array}{l}-0.001 \\
(0.001)\end{array}$ \\
\hline \multicolumn{4}{|l|}{ Parental education (High-skilled ref.) } \\
\hline Medium-skilled x Severity of disability & & & $\begin{array}{l}-0.002 * * \\
(0.001)\end{array}$ \\
\hline Low-skilled $x$ Severity of disability & & & $\begin{array}{l}-0.005^{\text {** }} \\
(0.002)\end{array}$ \\
\hline \multicolumn{4}{|l|}{ Other disabled HH members } \\
\hline Other adult(s) $\times$ Severity of disability & & & $\begin{array}{c}0.001 \\
(0.006)\end{array}$ \\
\hline Parent(s) $\times$ Severity of disability & & & $\begin{array}{l}-0.001 \\
(0.004)\end{array}$ \\
\hline Sibling $(s) \times$ Severity of disability & & $\begin{array}{l}-0.003 \\
(0.001)\end{array}$ & $\begin{array}{l}-0.002 \\
(0.001)\end{array}$ \\
\hline
\end{tabular}


Table A4.2. (Continued)

\begin{tabular}{|c|c|c|c|}
\hline Belgium (0-20y) & Model I & Model 2 & Model 3 \\
\hline \multicolumn{4}{|l|}{ Age of the child (0-3y ref.) } \\
\hline $4-5 y \times$ Severity of disability & & & $\begin{array}{l}-0.001 \\
(0.001)\end{array}$ \\
\hline $6-11 y \times$ Severity of disability & & & $\begin{array}{l}-0.003 * * \\
(0.001)\end{array}$ \\
\hline $12-17 y \times$ Severity of disability & & & $\begin{array}{l}-0.003 * * \\
(0.001)\end{array}$ \\
\hline 18-20y $\times$ Severity of disability & & & $\begin{array}{l}-0.004^{*} \\
(0.002)\end{array}$ \\
\hline \multicolumn{4}{|l|}{ Control variables } \\
\hline \multicolumn{4}{|l|}{ Age child (0-3y ref.) } \\
\hline $4-5 y$ & 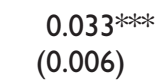 & $\begin{array}{l}0.033^{* * * *} \\
(0.006)\end{array}$ & $\begin{array}{l}0.033 * * * \\
(0.006)\end{array}$ \\
\hline $6-11 y$ & 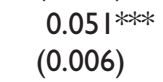 & $\begin{array}{l}0.05 I^{* * *} \\
(0.006)\end{array}$ & $\begin{array}{l}0.05 I^{* * *} \\
(0.006)\end{array}$ \\
\hline $12-17 y$ & 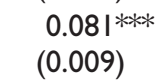 & $\begin{array}{l}0.08 I^{\text {**** }} \\
(0.009)\end{array}$ & $\begin{array}{l}0.082 \text { *** } \\
(0.009)\end{array}$ \\
\hline $18-20 y$ & $\begin{array}{l}0.098 * * * \\
(0.013)\end{array}$ & $\begin{array}{l}0.106 \text { *** } \\
(0.013)\end{array}$ & $\begin{array}{l}0.106 * * * \\
(0.013)\end{array}$ \\
\hline Male & $\begin{array}{l}-0.001 \\
(0.004)\end{array}$ & $\begin{array}{c}0.001 \\
(0.003)\end{array}$ & $\begin{array}{c}0.001 \\
(0.003)\end{array}$ \\
\hline \multicolumn{4}{|l|}{ Region of residence (Flanders ref.) } \\
\hline Brussels & $\begin{array}{l}-0.080^{* * * * *} \\
(0.011)\end{array}$ & $\begin{array}{l}-0.04 I^{* * * *} \\
(0.010)\end{array}$ & $\begin{array}{l}-0.041 * * * * \\
(0.010)\end{array}$ \\
\hline Wallonia & $\begin{array}{l}-0.040 \text { *** } \\
(0.004)\end{array}$ & $\begin{array}{l}-0.030 \text { *** } \\
(0.004)\end{array}$ & $\begin{array}{l}-0.030 \text { *** } \\
(0.004)\end{array}$ \\
\hline Age mother (centred around the mean) & $\begin{array}{l}-0.008^{\text {**** }} \\
(0.001)\end{array}$ & $\begin{array}{l}-0.007^{* * * * *} \\
(0.001)\end{array}$ & $\begin{array}{l}-0.007^{* * * *} \\
(0.001)\end{array}$ \\
\hline Number of siblings $(<2 \mathrm{l} y)$ & $\begin{array}{c}0.005 \\
(0.003)\end{array}$ & $\begin{array}{l}0.008^{* *} \\
(0.002)\end{array}$ & $\begin{array}{l}0.008 * * \\
(0.002)\end{array}$ \\
\hline \multicolumn{4}{|l|}{ Model fit } \\
\hline Log likelihood & 2675.39 & 4248.09 & 4253.34 \\
\hline $\mathrm{R}^{2}$ & 0.0576 & 0.1599 & 0.1602 \\
\hline Likelihood-ratio test compared to M-I & & 3145.40 & 10.51 \\
\hline Prob $>\mathrm{Chi}^{2}$ compared to $\mathrm{M}-\mathrm{I}$ & & 0.000 & 0.4850 \\
\hline $\mathbf{N}$ & 27379 & 27379 & 27379 \\
\hline
\end{tabular}

Source: own calculations based on DWH LM\&SP, year 2010 and Census, year 20II.

Notes: robust standard errors in parentheses. ${ }^{*} p<0.05$, ${ }^{* *} p<0.01$, *** $p<0.00$ I. 


\section{Appendix 5}

Further investigation of migration background

Table A5. I. Logistic regressions on having a disabled child, odds ratios, Belgium, 2010.

\begin{tabular}{lcl}
\hline $0-20 y$ & Model I (same as Table I) & Model 2 \\
\hline Constant & $0.003^{* * *}$ & $0.003^{* * * *}$ \\
& $(0.000)$ & $(0.000)$
\end{tabular}

Social categories

\begin{tabular}{|c|c|c|}
\hline Single parent & $\begin{array}{l}1.184 * * * \\
(0.037)\end{array}$ & $\begin{array}{l}\text { I.I } 77^{* * *} \\
(0.037)\end{array}$ \\
\hline \multicolumn{3}{|c|}{ Country of birth parent (Belgium ref.) } \\
\hline EU27 & $\begin{array}{l}0.670 * * * \\
(0.060)\end{array}$ & $\begin{array}{l}0.821 \\
(0.126)\end{array}$ \\
\hline Non-EU27 & $\begin{array}{l}0.848 * * \\
(0.051)\end{array}$ & $\begin{array}{l}1.117 \\
(0.122)\end{array}$ \\
\hline \multicolumn{3}{|c|}{ Parental education (High-skilled ref.) } \\
\hline Medium-skilled & $\begin{array}{l}1.477 \text { **** } \\
(0.041)\end{array}$ & $\begin{array}{l}1.49 I^{* * * *} \\
(0.043)\end{array}$ \\
\hline Low-skilled & $\begin{array}{l}1.703 \text { **** } \\
(0.067)\end{array}$ & $\begin{array}{l}\text { I.784**** } \\
(0.075)\end{array}$ \\
\hline \multicolumn{3}{|c|}{ Other disabled household member(s) (None ref.) } \\
\hline Yes, at least one & $\begin{array}{l}5.743 \text { **** } \\
(0.317)\end{array}$ & $\begin{array}{l}5.722 \text { **** } \\
(0.316)\end{array}$ \\
\hline
\end{tabular}

Interaction

\section{Country of birth parents $x$ Parental education}

EU27 x Medium-skilled

EU27 x Low-skilled

Non-EU27 x Medium-skilled

Non-EU27 x Low-skilled

Child characteristics

Age (0-3y ref.)
$4-5 y$
$2.437^{* * * *}$
$2.443 * * *$
$6-11 y$
(0.120)
(0.120)
$4.300 * * *$
$4.305^{* * * *}$
(0.159)
(0.159)
$12-17 y$
$4.231 * * * *$
$4.224 * * *$
(0.162)
(0.162)
18-20y
I.727***
I.718***
$(0.102)$
(0.101) 
Table A5.I. (Continued)

0-20y

Male

\section{Model fit}

Log pseudolikelihood

Pseudo R ${ }^{2}$

Prob $>\mathrm{Chi}^{2}$

Likelihood-ratio test compared to M-I

Prob $>\mathrm{Chi}^{2}$ compared to $\mathrm{M}$ - I

N
Model I (same as Table I)

Model 2

$1.645 * * *$

$1.647 * * *$

(0.043)

(0.044)

$-|60356.7|$

$-160320.20$

0.0733

0.0735

0.000

0.000

73.02

0.000

35415

35415

Source: own calculations on DWH LM\&SP, year 2010 and Census, year $201 \mathrm{I}$.

Notes: no disability is base outcome. Robust standard errors in parentheses. $* \mathrm{p}<0.05 ; * * \mathrm{p}<0.0 \mathrm{I}$; *** $\mathrm{p}<0.00 \mathrm{I}$. Odds ratio's $<\mathrm{I}$ indicate a lower risk to have a disability, odds ratio's $>\mathrm{I}$ indicate a higher risk, compared to the reference category.

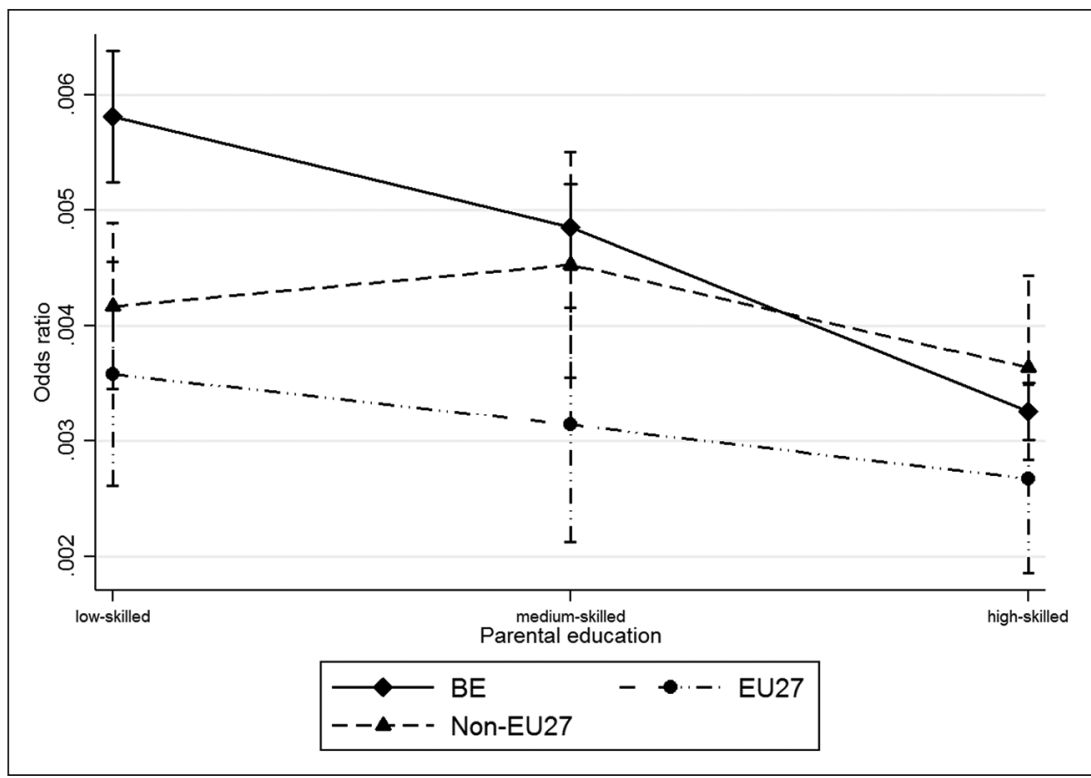

Figure A5. I. Marginal effects of country of birth parents and parental education on having a child with a disability, Model 2, Belgium, 2010.

Source: own calculations based on DWH LM\&SP, year 2010 and Census, year 201 I.

Notes: marginal effects from Model 2, shown at reference values for age and gender of the child, household type, and whether or not there are other disabled household members. 


\section{Appendix 6}

Social category and disability effect for children with - I standard deviation and $+I$ standard deviation from the mean severity score

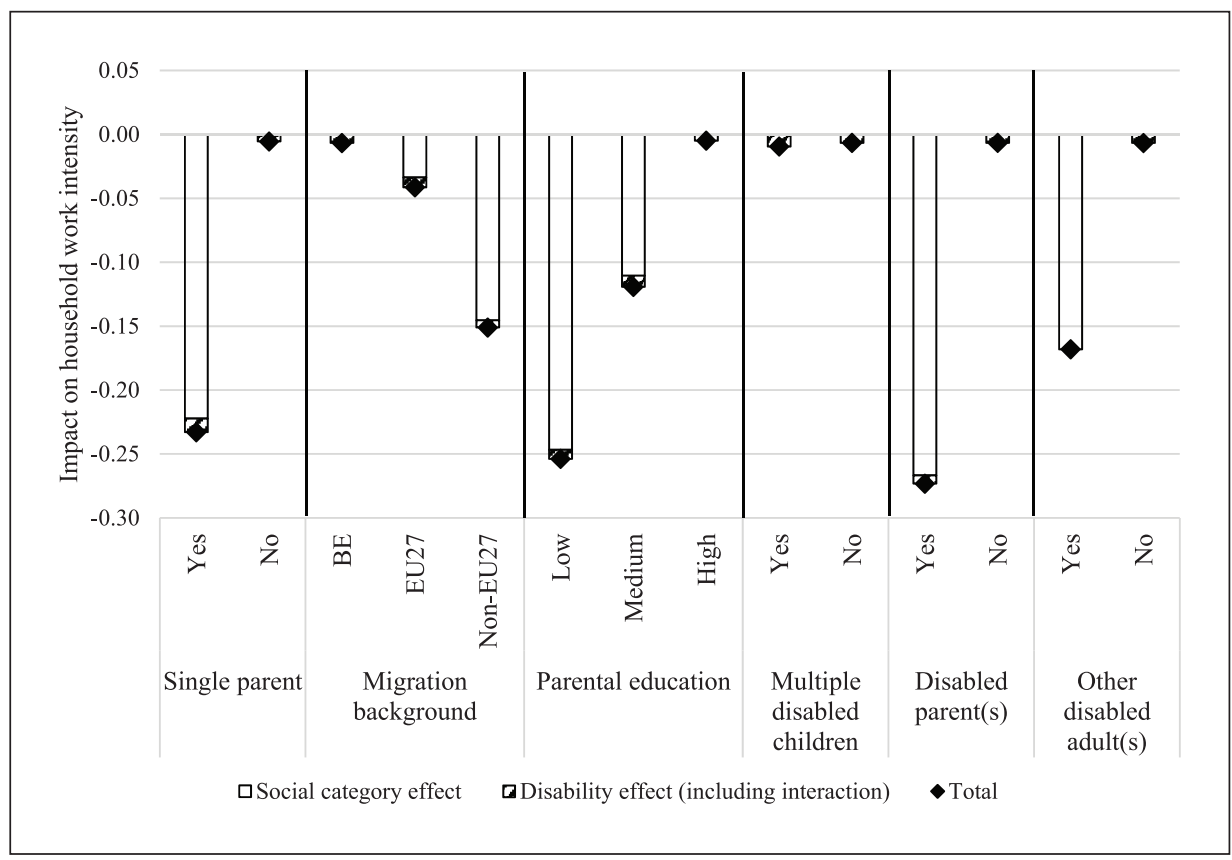

Figure A6. I. Marginal effects of having a disabled child with - I SD severity score on household work intensity by social category, for average values of other variables in Model 3 from Table 2, Belgium, 2010.

Source: own calculations based on DWH LM\&SP, year 2010 and Census, year 2011 .

Notes: the figure presents the marginal effect on household work intensity by social category for families with a disabled child who has a - I standard deviation from the mean severity score (5.9) I 886 ( 0.91 I 884 on the recoded scale)). 


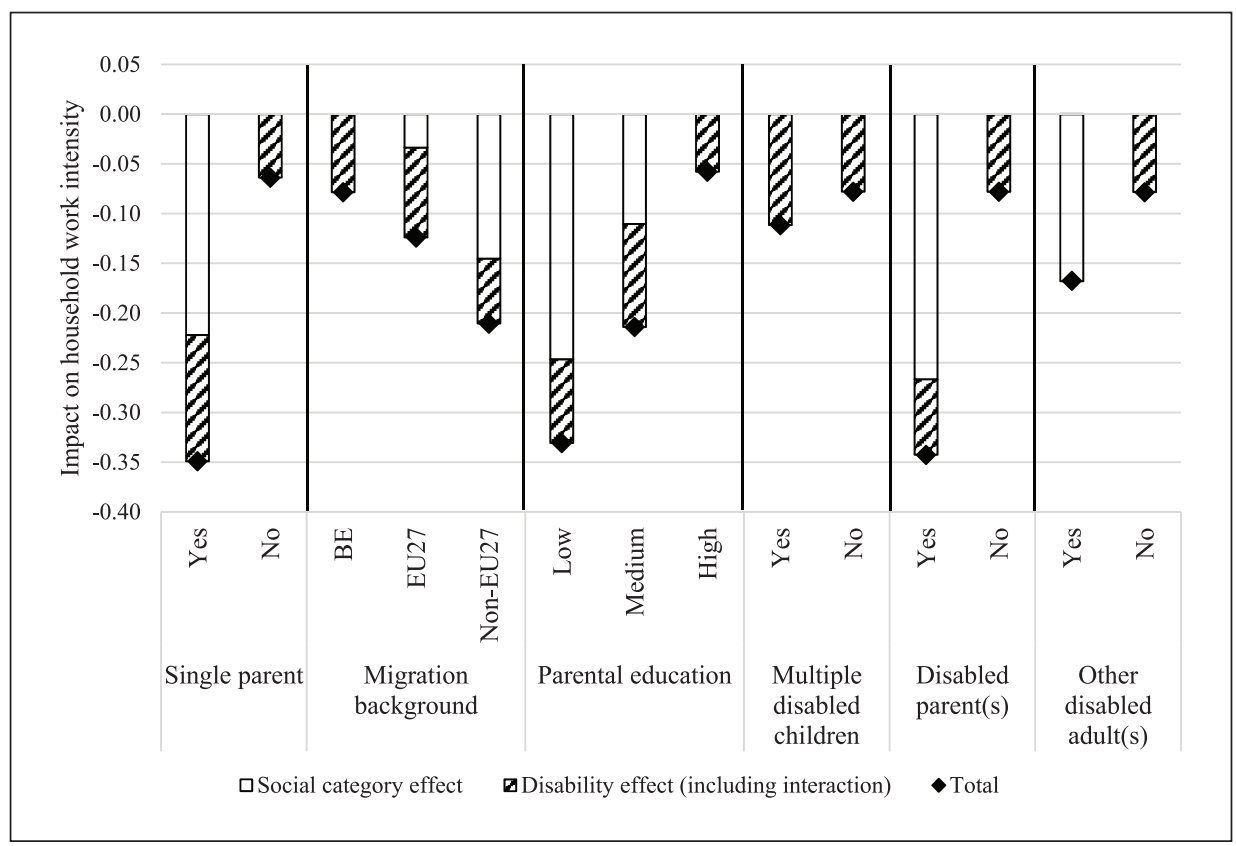

Figure A6.2. Marginal effects of having a disabled child with + I SD severity score on household work intensity by social category, for average values of other variables in Model 3 from Table 2, Belgium, 2010.

Source: own calculations based on DWH LM\&SP, year 2010 and Census, year 2011 .

Notes: the figure presents the marginal effect on household work intensity by social category for families with a disabled child who has a + I standard deviation from the mean severity score (I5.774634 (I 0.774632 on the recoded scale)). 